Prepared in cooperation with the U.S. Fish and Wildlife Service

Optimization of Salt Marsh Management at the Moosehorn National Wildlife Refuge, Maine, Through Use of Structured Decision Making

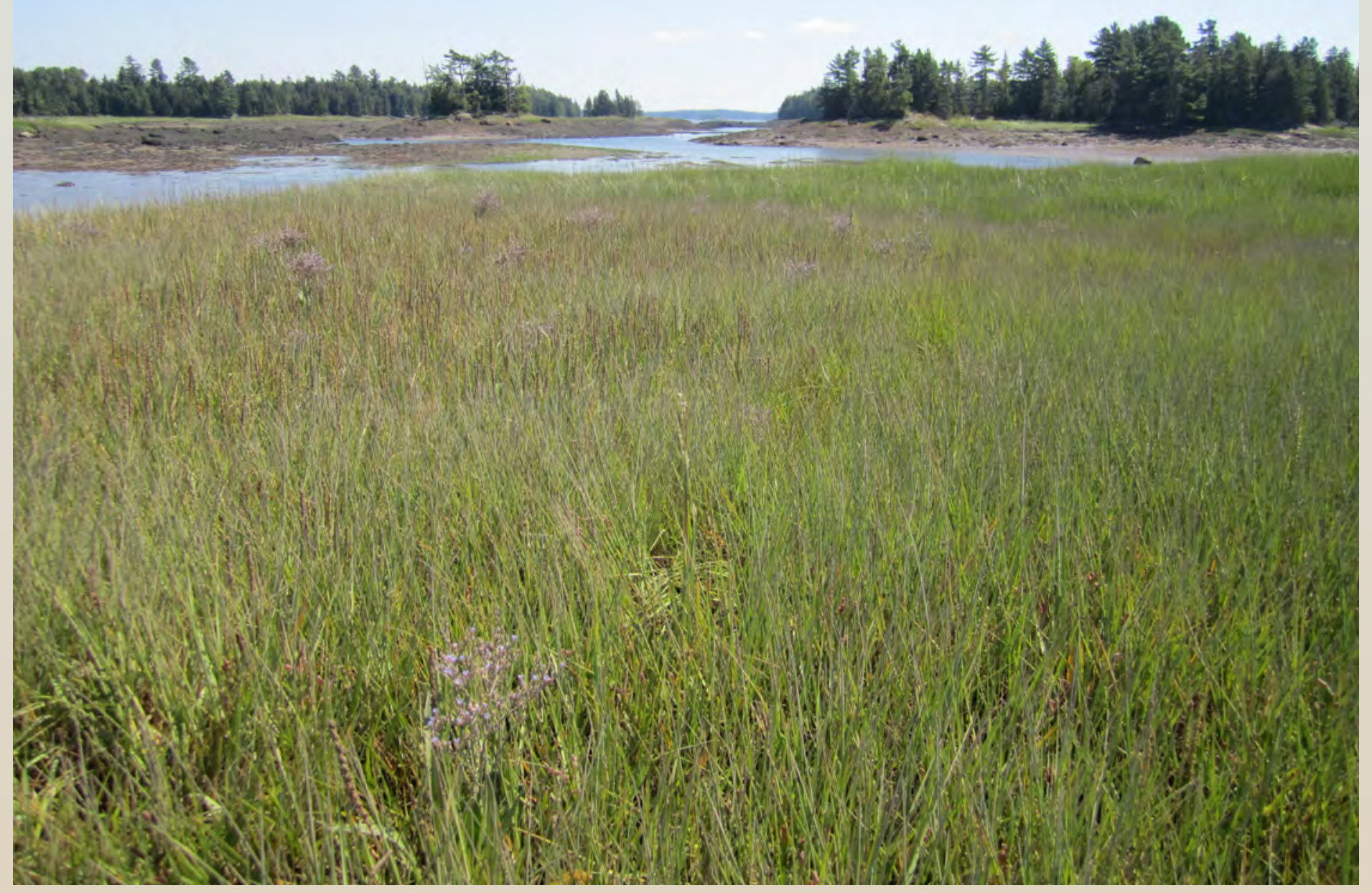

Open-File Report 2021-1115 
Photograph of Ox Cove salt marsh at Moosehorn National Wildlife Refuge, Edmunds Division, Pembroke, Maine; photograph by U.S. Fish and Wildlife Service. 


\section{Optimization of Salt Marsh Management at the Moosehorn National Wildlife Refuge, Maine, Through Use of Structured Decision Making}

By Hilary A. Neckles, James E. Lyons, Jessica L. Nagel, Susan C. Adamowicz, Toni Mikula, Maurice Mills, Raymond E. Brown, and Keith Ramos

Prepared in cooperation with the U.S. Fish and Wildlife Service

Open-File Report 2021-1115 


\section{U.S. Geological Survey, Reston, Virginia: 2021}

For more information on the USGS - the Federal source for science about the Earth, its natural and living resources, natural hazards, and the environment—visit https://www.usgs.gov or call 1-888-ASK-USGS.

For an overview of USGS information products, including maps, imagery, and publications, visit https://store.usgs.gov/.

Any use of trade, firm, or product names is for descriptive purposes only and does not imply endorsement by the U.S. Government.

The findings and conclusions in this report are those of the authors and do not necessarily represent the views of the U.S. Fish and Wildlife Service.

Although this information product, for the most part, is in the public domain, it also may contain copyrighted materials as noted in the text. Permission to reproduce copyrighted items must be secured from the copyright owner.

Suggested citation:

Neckles, H.A., Lyons, J.E., Nagel, J.L., Adamowicz, S.C., Mikula, T., Mills, M., Brown, R.E., and Ramos, K., 2021, Optimization of salt marsh management at the Moosehorn National Wildlife Refuge, Maine, through use of structured decision making: U.S. Geological Survey Open-File Report 2021-1115, 28 p., https://doi.org/10.3133/ofr20211115.

Associated data for this publication:

U.S. Fish and Wildlife Service, 2016, Salt marsh integrity and Hurricane Sandy vegetation, bird and nekton data: U.S. Fish and Wildlife Service database, https://ecos.fws.gov/ServCat/Reference/Profile/121918.

ISSN 2331-1258 (online) 


\section{Acknowledgments}

Ward Feurt, Ryan Kleinert, Kathleen O'Brien, and Bri Benvenuti of the U.S. Fish and Wildlife Service (FWS) provided exceptional hospitality at the Rachel Carson National Wildlife Refuge, Maine, for the 2018 structured decision-making workshop, which included participants from six additional national wildlife refuges. Nathan Bush of the FWS generated the mapping data used in this report, and Jackie Olson of the U.S. Geological Survey expertly prepared the maps. Technical reviews by Rachel Katz of the FWS and Bill Thompson of the National Park Service greatly improved the quality of this report. 



\section{Contents}

Acknowledgments ……...................................................................................................................

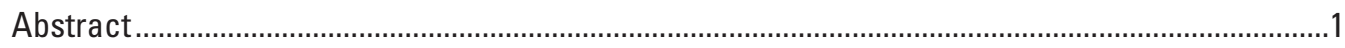

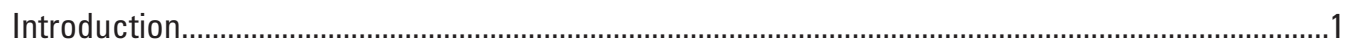

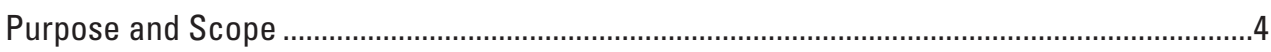

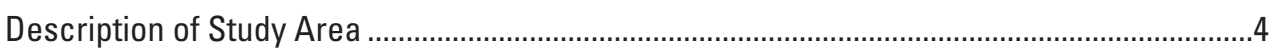

Regional Structured Decision-Making Framework ……........................................................

Application to the Moosehorn National Wildlife Refuge ...............................................................

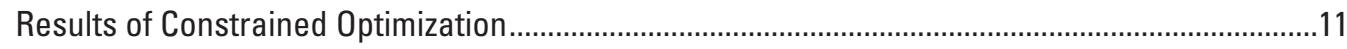

Considerations for Optimizing Salt Marsh Management..............................................................14

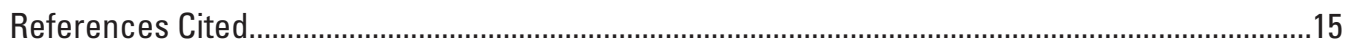

Appendix 1. Regional Influence Diagrams ..........................................................................17

Appendix 2. Utility Functions for the Moosehorn National Wildlife Refuge ..................................24

\section{Figures}

1. Map showing national wildlife refuges and national wildlife refuge complexes of the U.S. Fish and Wildlife Service where salt marsh integrity was assessed from 2012 to 2016 using the regional monitoring protocol ...................................................2

2. Map showing salt marsh management units at the Edmunds Division of the Moosehorn National Wildlife Refuge in Maine

3. Graph showing predicted total management benefit of various portfolios, expressed as weighted utilities, relative to total cost at the Edmunds Division of the Moosehorn National Wildlife Refuge in Maine

4. Bar chart showing predicted management benefit of portfolio 3 in comparison to the management benefit from the baseline "no-action" portfolio at the Edmunds Division of the Moosehorn National Wildlife Refuge in Maine

\section{Tables}

1. Objectives hierarchy for salt marsh management decision problems

2. Participants in the workshop convened at the Rachel Carson National Wildlife Refuge, Maine, to apply a regional framework for optimizing salt marsh management decisions to six national wildlife refuges in January 2018.

3. Possible management actions for achieving objectives within four marsh management units at the Edmunds Division of the Moosehorn National Wildlife Refuge, Maine, estimated costs over 5 years, and predicted outcomes expressed relative to performance metrics.

4. Normalized predicted outcomes and estimated total management benefits of possible management actions within four marsh management units at the Edmunds Division of the Moosehorn National Wildlife Refuge, Maine

5. Actions included in various management portfolios to maximize the total management benefits subject to increasing cost constraints at the Edmunds Division of the Moosehorn National Wildlife Refuge, Maine. 


\section{Conversion Factors}

International System of Units to U.S. customary units

\begin{tabular}{|c|c|c|}
\hline Multiply & By & To obtain \\
\hline meter $(\mathrm{m})$ & 3.281 & foot (ft) \\
\hline kilometer (km) & 0.6214 & mile (mi) \\
\hline square meter $\left(\mathrm{m}^{2}\right)$ & 0.0002471 & acre \\
\hline hectare (ha) & 2.471 & acre \\
\hline
\end{tabular}

\section{Datums}

Vertical coordinate information is referenced to the North American Vertical Datum of 1988 (NAVD 88).

Horizontal coordinate information is referenced to the North American Datum of 1983 (NAD 83).

Elevation, as used in this report, refers to distance above the vertical datum.

\section{Abbreviations}

FWS U.S. Fish and Wildlife Service

NWR national wildlife refuge

ppt part per thousand

USGS U.S. Geological Survey 


\title{
Optimization of Salt Marsh Management at the Moosehorn National Wildlife Refuge, Maine, Through Use of Structured Decision Making
}

\author{
By Hilary A. Neckles, ${ }^{1}$ James E. Lyons, ${ }^{1}$ Jessica L. Nagel,, Susan C. Adamowicz, ${ }^{2}$ Toni Mikula, ${ }^{2}$ \\ Maurice Mills, ${ }^{2}$ Raymond E. Brown, ${ }^{2}$ and Keith Ramos ${ }^{2}$
}

\section{Abstract}

Structured decision making is a systematic, transparent process for improving the quality of complex decisions by identifying measurable management objectives and feasible management actions; predicting the potential consequences of management actions relative to the stated objectives; and selecting a course of action that maximizes the total benefit achieved and balances tradeoffs among objectives. The U.S. Geological Survey, in cooperation with the U.S. Fish and Wildlife Service, applied an existing, regional framework for structured decision making to develop a prototype tool for optimizing tidal marsh management decisions at the Moosehorn National Wildlife Refuge in Maine. Refuge biologists, refuge managers, and research scientists identified multiple potential management actions to improve the ecological integrity of four marsh management units within the refuge, totaling about 13 hectares, and estimated the outcomes of each action in terms of performance metrics associated with each management objective. Value functions previously developed at the regional level were used to transform metric scores to a common utility scale, and utilities were summed to produce a single score representing the total management benefit that could be accrued from each potential management action. Constrained optimization was used to identify the set of management actions, one per marsh management unit, that could maximize total management benefits at different cost constraints at the refuge scale. Results indicated that, for the objectives and actions considered here, total management benefits may increase consistently up to $\$ 1,000$, and may continue to increase at a lower rate with further expenditures. Potential management actions in optimal portfolios at total costs less than or equal to $\$ 1,000$ included improving nesting habitat for Ammodramus nelsoni (Nelson's sparrow) or restoring hydrologic connections to the upper marsh in one marsh management unit (Hobart Stream West). The potential management benefits were derived from expected increases in the density of

${ }^{1}$ U.S. Geological Survey.

${ }^{2}$ U.S. Fish and Wildlife Service. nekton and of spiders (as an indicator of trophic health). The prototype presented here does not resolve management decisions; rather, it provides a framework for decision making at the Moosehorn National Wildlife Refuge that can be updated for implementation as new data and information become available. Insights from this process may also be useful to inform future habitat management planning at the refuge.

\section{Introduction}

The National Wildlife Refuge System protects extensive salt marsh acreage in the northeastern United States. Much of this habitat has been degraded by a succession of human activities since the time of European settlement (Gedan and others, 2009), and accelerated rates of sea-level rise exacerbate these effects (Gedan and others, 2011; Kirwan and Megonigal, 2013). Therefore, strategies to restore and enhance the ecological integrity of national wildlife refuge (NWR) salt marshes are regularly considered. Management may include such activities as reestablishing natural hydrology, augmenting or excavating sediments to restore marsh elevation, controlling invasive species, planting native vegetation, minimizing shoreline erosion, and remediating contaminant problems. Uncertainty stemming from incomplete knowledge of system status and imperfect understanding of ecosystem dynamics commonly hinders management predictions and selection of the most effective management options. Consequently, tools for identifying appropriate assessment variables and evaluating tradeoffs among management objectives are valuable to inform marsh management decisions.

Structured decision making is a systematic approach to improving the quality of complex decisions that integrates assessment metrics into the decision process (Gregory and Keeney, 2002). This approach involves identifying measurable management objectives and potential management actions, predicting management outcomes, and evaluating tradeoffs to choose a preferred alternative. From 2008 to 2012, the U.S. Geological Survey (USGS) and U.S. Fish and Wildlife Service (FWS) used structured decision making to develop a 
framework for optimizing management decisions for NWR salt marshes in the FWS Northeast Region (that is, salt marshes in the coastal region from Maine through Virginia). The structured decision-making steps were applied through successive "rapid prototyping" workshops, an iterative process in which relatively short periods of time are invested to continually improve the decision structure (Blomquist and others, 2010; Garrard and others, 2017). The decision framework includes regional management objectives addressing critical components of salt marsh ecosystems, and associated performance metrics for determining whether objectives are achieved (Neckles and others, 2015). The regional objectives structure served as the foundation for a consistent protocol for monitoring salt marsh integrity at these northeastern coastal refuges, in which the monitoring variables are linked explicitly to management goals (Neckles and others, 2013). From 2012 to 2016, this protocol was used to conduct a baseline assessment of salt marsh integrity at all 17 refuges or refuge complexes in the FWS Northeast Region with salt marsh habitat (fig. 1).

The Moosehorn National Wildlife Refuge is one of the northernmost national wildlife refuges along the U.S. Atlantic coast. The refuge's salt marsh borders the tidal waters of Dennys Bay (fig. 2), within inner Cobscook Bay, Maine. The salt marsh provides habitat for birds identified as conservation priorities, including Anas rubripes (American black ducks) and Ammospiza nelsoni (Nelson's sparrows), in the New England and mid-Atlantic coast bird conservation region of the U.S. North American Bird Conservation Initiative (Steinkamp, 2008; U.S. North American Bird Conservation

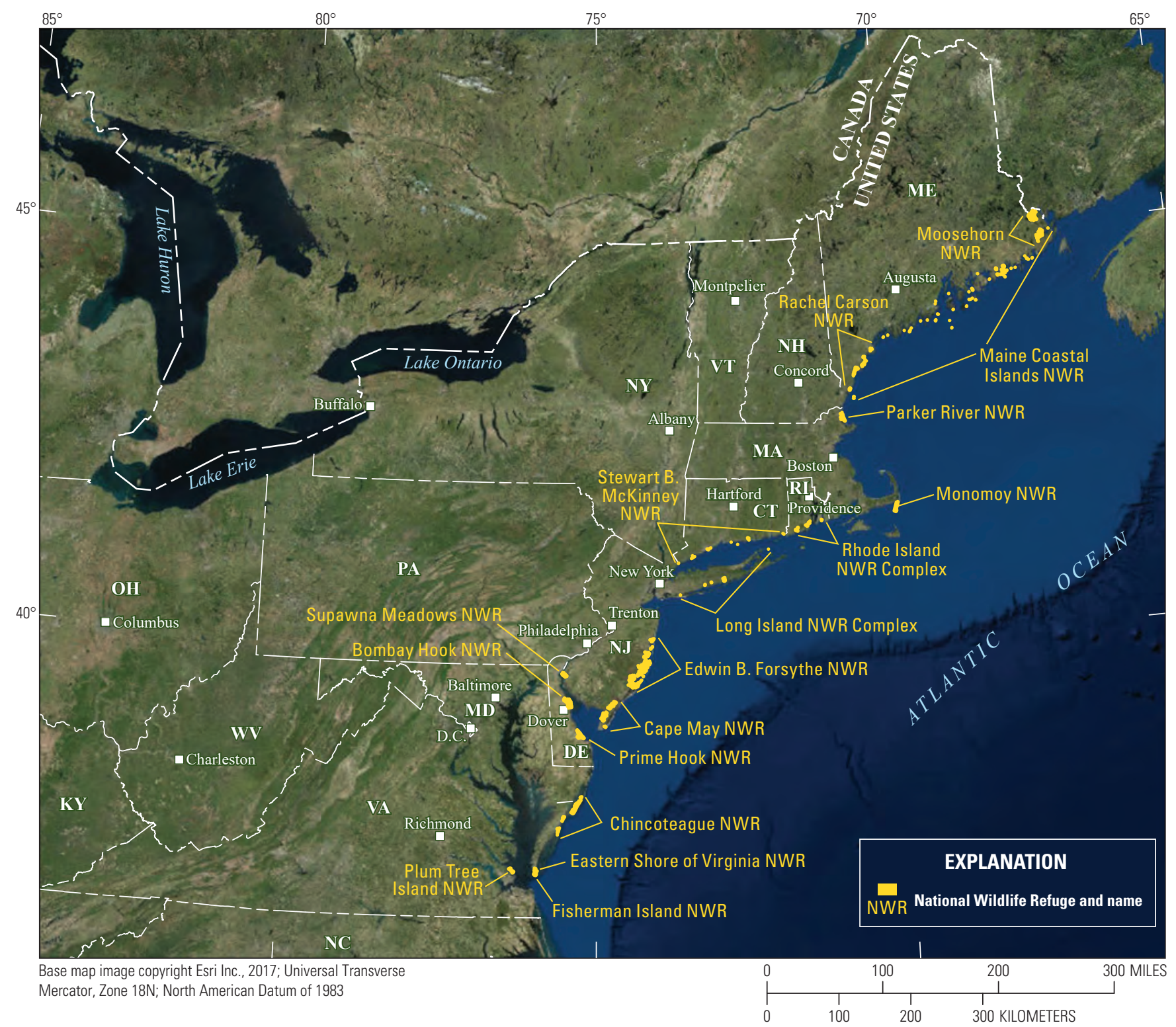

Figure 1. Map showing national wildlife refuges and national wildlife refuge complexes of the U.S. Fish and Wildlife Service where salt marsh integrity was assessed from 2012 to 2016 using the regional monitoring protocol. 


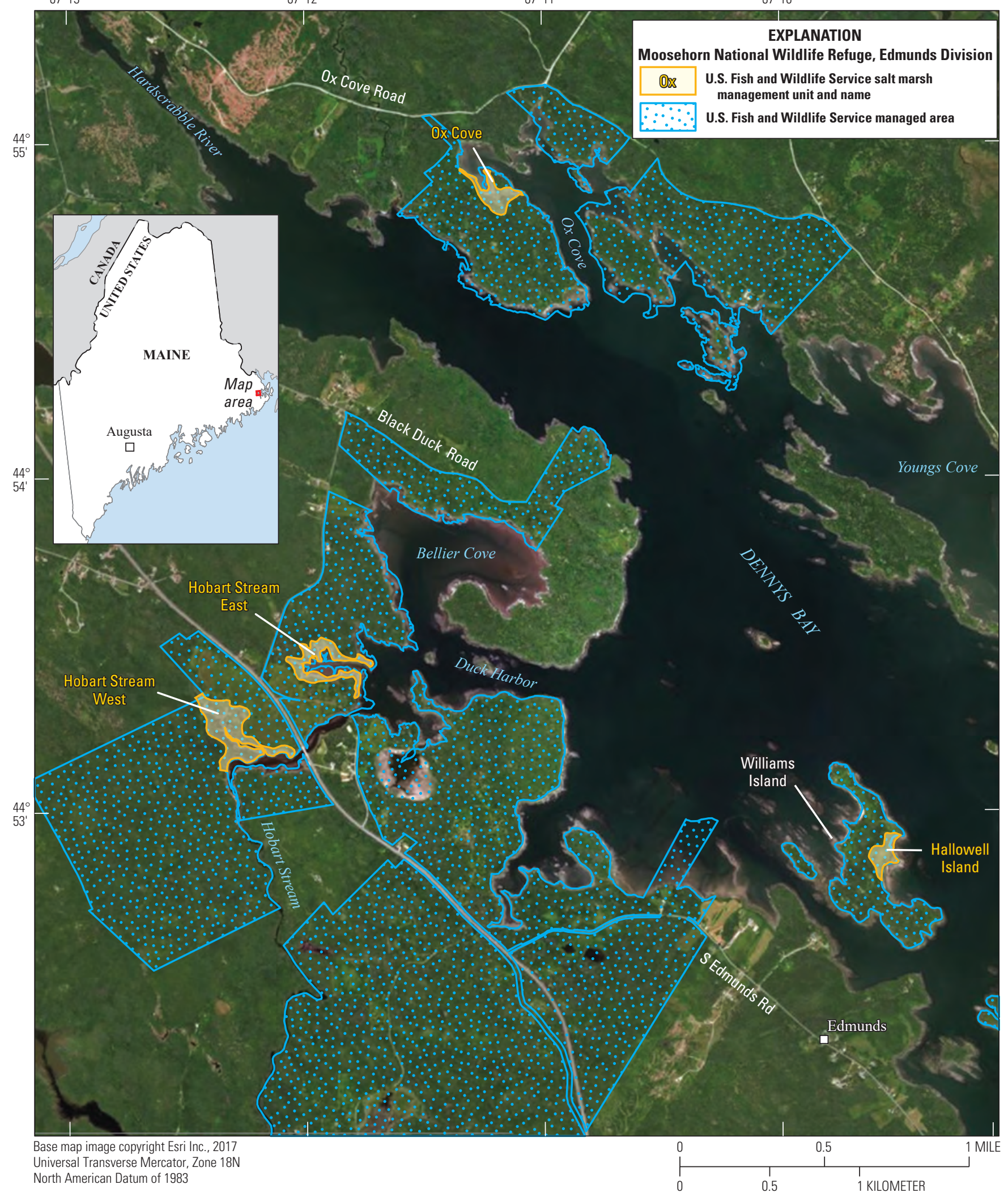

Figure 2. Map showing salt marsh management units at the Edmunds Division of the Moosehorn National Wildlife Refuge in Maine. U.S. Fish and Wildlife Service managed areas shown for reference. Williams Island is locally known as Hallowell Island. 
Initiative, 2020). The salt marsh also provides foraging habitat for wading birds during breeding and migratory seasons. Salt marshes in this region of the Maine coast are generally small (mean area of 2 hectares [ha]; Jacobson and others, 1987), with thin peat deposits and limited sediment supply, and are subject to a rapid rate of local sea-level rise (Kelley and others, 1988). Management goals set by the FWS for the refuge include maintaining and enhancing salt marsh habitat for migratory birds. In this study, the regional structured decisionmaking framework was used to help prioritize salt marsh management options for the refuge.

\section{Purpose and Scope}

This report describes the application of the regional structured decision-making framework (Neckles and others, 2015) to the Moosehorn National Wildlife Refuge. The regional framework was parameterized to local conditions through rapid prototyping, producing a decision model for the refuge that can be updated as new information becomes available. Included are a suite of potential management actions to achieve objectives in four marsh management units at the Edmunds Division of the refuge (fig. 2), estimated costs for implementing each potential action, predictions for the outcome of each management action relative to individual management objectives, and results of constrained optimization to maximize management benefits subject to cost constraints. This decision structure can be used to understand how specific actions may contribute to achieving management objectives and identify an optimum combination of actions, or "management portfolio," to maximize management benefits at the refuge scale for a range of potential budgets. The prototype presented here provides a framework for continually improving the quality of complex management decisions at the Moosehorn National Wildlife Refuge.

\section{Description of Study Area}

The Moosehorn National Wildlife Refuge consists of two divisions in northeastern Maine (fig. 1). The northernmost Baring Division is inland, southwest of Calais, Maine. The Edmunds Division is on the coast of Dennys Bay within inner Cobscook Bay, and includes four small salt marsh management units ranging in size from 1.4 ha (Hallowell Island marsh management unit, on Williams Island) to 6.4 ha (Hobart Stream West; fig. 2). The salt marsh management units are minimally altered by human activities and most of the land within 1,000 meters of the unit boundaries is forested, with scattered houses and small farms. Cobscook Bay is a macrotidal system with a mean tidal range of 5.7 meters (Brooks, 2004). All salt marsh management units are well flushed with oceanic water except for Hobart Stream West, where a box culvert under the road at the mouth of the small embayment restricts flow from Dennys Bay. During summer 2012, average salt marsh surface-water salinities were about 25 parts per thousand (ppt) at Hallowell Island, 30 ppt at Hobart Stream
West, 31 ppt at Ox Cove, and 32 ppt at Hobart Stream East marsh management units (FWS, 2016), or polyhaline to euhaline as defined by Cowardin and others (1979).

\section{Regional Structured Decision-Making Framework}

A regional framework for assessing and managing salt marsh integrity at northeastern NWRs was developed through collaborative efforts of FWS regional and refuge managers and biologists, salt marsh research scientists, and structured decision-making experts. This process followed the discrete steps outlined by Hammond and others (1999) and Gregory and Keeney (2002):

1. Clarify the temporal and spatial scope of the management decision.

2. Define objectives and performance measures to evaluate whether objectives are achieved.

3. Develop alternative management actions for achieving objectives.

4. Estimate the consequences or likely outcomes of management actions in terms of the performance measures.

5. Evaluate the tradeoffs inherent in potential alternatives and select the optimum alternatives to maximize management benefits.

This sequence of steps was applied through successive workshops to refine the decision structure and incorporate newly available information. Initial development of the structured decision-making framework occurred during a weeklong workshop in 2008 to define the decision problem, specify management objectives, and explore potential strategies available to restore and enhance salt marsh integrity. During 2008 and 2009, workshop results were used to guide field tests of salt marsh monitoring variables (Neckles and others, 2013). Subsequently, in 2012, data and insights gained from these field tests were used in a two-part workshop to refine management objectives and develop the means for evaluating management outcomes (Neckles and others, 2015).

From the outset, FWS goals included development of an approach for consistent assessment of salt marsh integrity across all northeastern NWRs (fig. 1). Within this regional context, staff at a given refuge must periodically determine the best approaches for managing salt marshes to maximize habitat value while considering financial and other constraints. The salt marsh decision problem was thus defined as applying to individual NWRs over a 5-year planning horizon. The objectives for complex decisions can be organized into a hierarchy to help clarify what is most important to decision makers (Gregory and others, 2012). The hierarchy of objectives for salt marsh management decisions (table 1) was based explicitly on the conservation mission of the National Wildlife Refuge System, which is upheld through FWS management 
Table 1. Objectives hierarchy for salt marsh management decision problems.

[Two fundamental objectives (overall goals of the decision problem) draw directly from U.S. Fish and Wildlife Service (FWS) National Wildlife Refuge System policy to maintain, restore, and enhance biological integrity, diversity, and environmental health within the refuge. These are broken down into lower level objectives focused on specific aspects of marsh structure and function. Values in parentheses are weights assigned to objectives, reflecting their relative importance. Weights on any branch of the hierarchy (that is, objectives that are at the same level of the hierarchy under a fundamental objective) sum to one. The weight for each metric is the product of the weights from each level of the hierarchy leading to that metric. See also Neckles and others (2015). NA, not applicable]

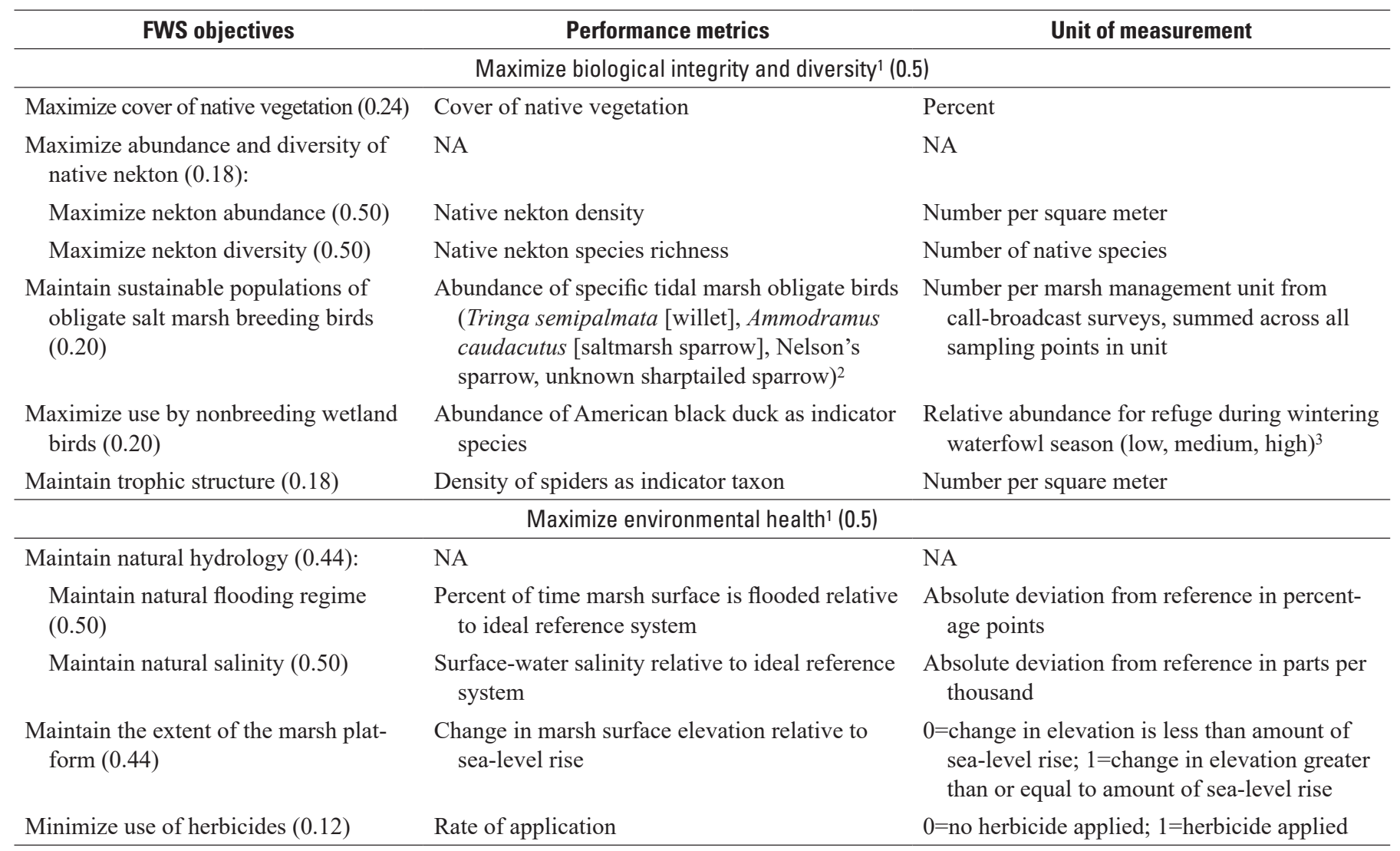

${ }^{1}$ Fundamental objectives of salt marsh management decisions.

${ }^{2}$ Species composition adjusted from regional performance metric to reflect bird geographic ranges relative to the Moosehorn National Wildlife Refuge. "Unknown sharptailed sparrow" includes saltmarsh sparrow, Nelson's sparrow, and hybrids between the two species.

${ }^{3}$ Relative abundance based on local knowledge.

to "ensure that the biological integrity, diversity, and environmental health of the System are maintained for the benefit of present and future generations of Americans," as mandated in the National Wildlife Refuge System Improvement Act of 1997 (16 U.S.C. §668dd note). Two fundamental objectives, or the overall goals for salt marsh management decisions, were drawn from this policy to maximize (1) biological integrity and diversity, and (2) environmental health, of salt marsh ecosystems. Participants in the prototyping workshops deconstructed these overall goals into lower-level objectives relating to salt marsh structure and function and identified performance metrics to evaluate whether objectives are achieved (table 1). In addition, performance metrics were weighted to reflect the relative importance of each objective (Neckles and others, 2015).

The hierarchy of objectives for salt marsh management (table 1) provides the foundation for identifying possible management actions at individual NWRs and predicting management outcomes. Workshop participants developed preliminary influence diagrams (app. 1), or conceptual models relating management actions to responses by each performance metric (Conroy and Peterson, 2013), to guide this process. To allow metric responses to be aggregated into a single, overall performance score, participants also defined value functions relating salt marsh integrity metric scores to perceived management benefit on a common, unitless "utility" scale (Keeney and Raiffa, 1993). Stakeholder elicitation was used to determine the form of each value function relating the original metric scale to the utility scale, ranging from 0 , representing the lowest management benefit, to 1 , representing the highest benefit (app. 2). Neckles and others (2015) provided details regarding development of the structured decisionmaking framework and a case-study application to Prime Hook National Wildlife Refuge in Delaware. 


\section{Application to the Moosehorn National Wildlife Refuge}

In January 2018, FWS regional biologists, biologists and managers from seven northeastern NWR administrative units, and USGS and Yale University research scientists (table 2) participated in a 1.5-day rapid-prototyping workshop to apply the regional structured decision-making framework to the Maine Coastal Islands, Monomoy, Moosehorn, Parker River, Rachel Carson, and Stewart B. McKinney National Wildlife Refuges. Participants worked within refuge-specific small groups to focus on management issues at individual refuges. Plenary discussions of common patterns of salt marsh degradation, potential management strategies, and mechanisms of ecosystem response offered additional insights to enhance refuge-specific discussions.

Participants identified a range of possible management actions for achieving objectives within each marsh management unit at the Moosehorn National Wildlife Refuge and estimated the total cost of implementation over a 5-year period; the specific years of implementation were not identified in this prototype. Potential actions to enhance salt marsh integrity included restoring hydrologic connections, improving songbird nesting habitat, altering marsh elevation, or facilitating marsh migration (table 3). Participants predicted the outcomes of each management action 5 years after initial implementation in terms of salt marsh integrity performance metrics. For most metrics, baseline conditions within each unit measured during the 2012-16 salt marsh integrity assessment (FWS, 2016) were used to predict the outcomes of a "no-action" alternative. Baseline conditions were estimated by using expert judgement for three metrics that lacked assessment data (abundance of American black ducks, density of spiders, change in marsh surface elevation relative to sea-level rise). Regional influence diagrams relating management strategies to outcomes aided in predicting consequences of management actions (app. 1). Although the influence diagrams incorporated the potential effects of stochastic processes, including weather, sea-level rise, herbivory, contaminant inputs, and disease, on management outcomes, no attempt was made to quantify these sources of uncertainty during rapid prototyping. Management predictions also inherently included considerable uncertainty surrounding the complex interactions among controlling factors and salt marsh ecosystem components.

Following the workshop, the potential management benefit of each salt marsh integrity performance metric was calculated by converting salt marsh integrity metric scores (table 3, workshop output) to weighted utilities (table 4) using regional value functions (app. 2). Weighted utilities were summed across all salt marsh integrity metrics for each action; this overall utility therefore represented the total management benefit, across all objectives, expected to accrue from a given management action (table 4). Constrained optimization (Conroy and Peterson, 2013) was used to find the management portfolio (the combination of actions, one action per marsh
Table 2. Participants in the workshop convened at the Rachel Carson National Wildlife Refuge, Maine, to apply a regional framework for optimizing salt marsh management decisions to six national wildlife refuges in January 2018.

[FWS, U.S. Fish and Wildlife Service; NWR, National Wildlife Refuge; USGS, U.S. Geological Survey]

\begin{tabular}{|c|c|}
\hline Affiliation & Participant \\
\hline \multicolumn{2}{|l|}{ FWS NWR specialists } \\
\hline Maine Coastal Islands NWR & Sara Williams \\
\hline Monomoy NWR & Matthew Hillman \\
\hline Moosehorn NWR & Maurice Mills \\
\hline Moosehorn NWR & Keith Ramos \\
\hline Moosehorn NWR & Ray Brown \\
\hline Parker River NWR & Nancy Pau \\
\hline Parker River NWR & Bill Peterson \\
\hline Rachel Carson NWR & Kathleen O'Brien \\
\hline Rachel Carson NWR & Ryan Kleinert \\
\hline Rachel Carson NWR & Bri Benvenuti \\
\hline Stewart B. McKinney NWR & Richard Potvin \\
\hline Stewart B. McKinney NWR & Kristina Vagos \\
\hline \multicolumn{2}{|l|}{ FWS regional experts } \\
\hline Northeast Regional Office & Rachel Katz \\
\hline Northeast Regional Office & Troy Wilson \\
\hline Rachel Carson NWR & Susan Adamowicz \\
\hline \multicolumn{2}{|l|}{ Research scientists } \\
\hline USGS Eastern Ecological Science Center & James Lyons \\
\hline USGS Eastern Ecological Science Center & Hilary Neckles \\
\hline $\begin{array}{l}\text { Yale School of Forestry and Environmental } \\
\text { Studies }\end{array}$ & Laurel Low \\
\hline
\end{tabular}

management unit) that maximizes the total management benefit across all units under varying cost scenarios for the entire refuge. Constrained optimization using integer linear programming was implemented in the Solver tool in Microsoft Excel (Kirkwood, 1997).

Budget constraints were increased in $\$ 500$ increments up to $\$ 2,500$; in $\$ 2,500$ increments up to $\$ 10,000$; in $\$ 10,000$ increments up to $\$ 100,000$; in $\$ 25,000$ increments up to $\$ 200,000$; in $\$ 50,000$ increments up to $\$ 300,000$; and in $\$ 100,000$ increments thereafter. The upper limit to potential costs was not determined in advance; rather, it reflected the total estimated costs of the proposed management actions. A cost-benefit plot of the portfolios identified through the optimization analysis was used to identify the efficient frontier for resource allocation (Keeney and Raiffa, 1993), which is the set of portfolios that are not dominated by other portfolios at similar costs (or the set of portfolios with maximum total benefit for a similar cost). The cost-benefit plot also revealed the cost above which further expenditures would yield diminishing returns on investment. To exemplify use of 


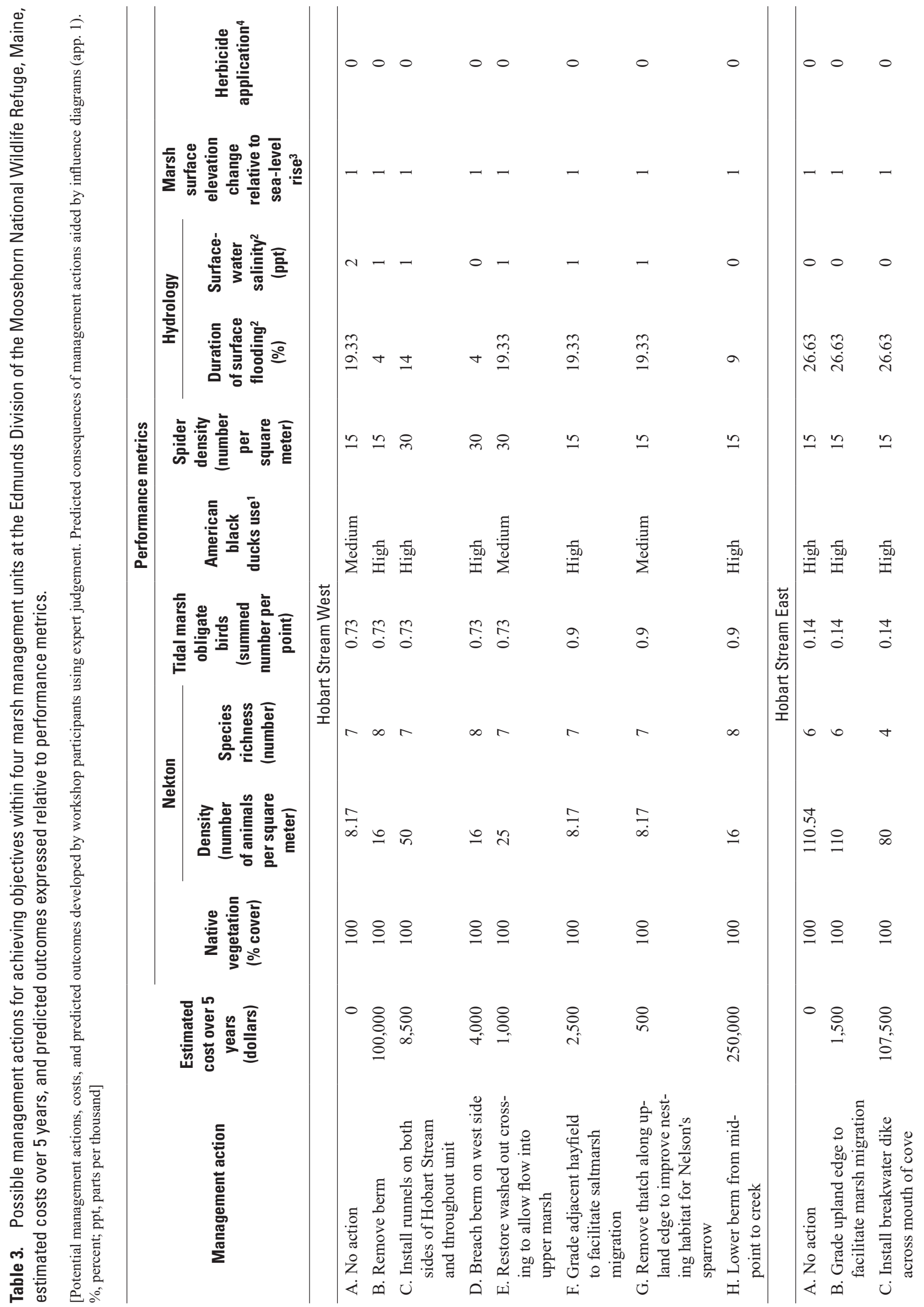




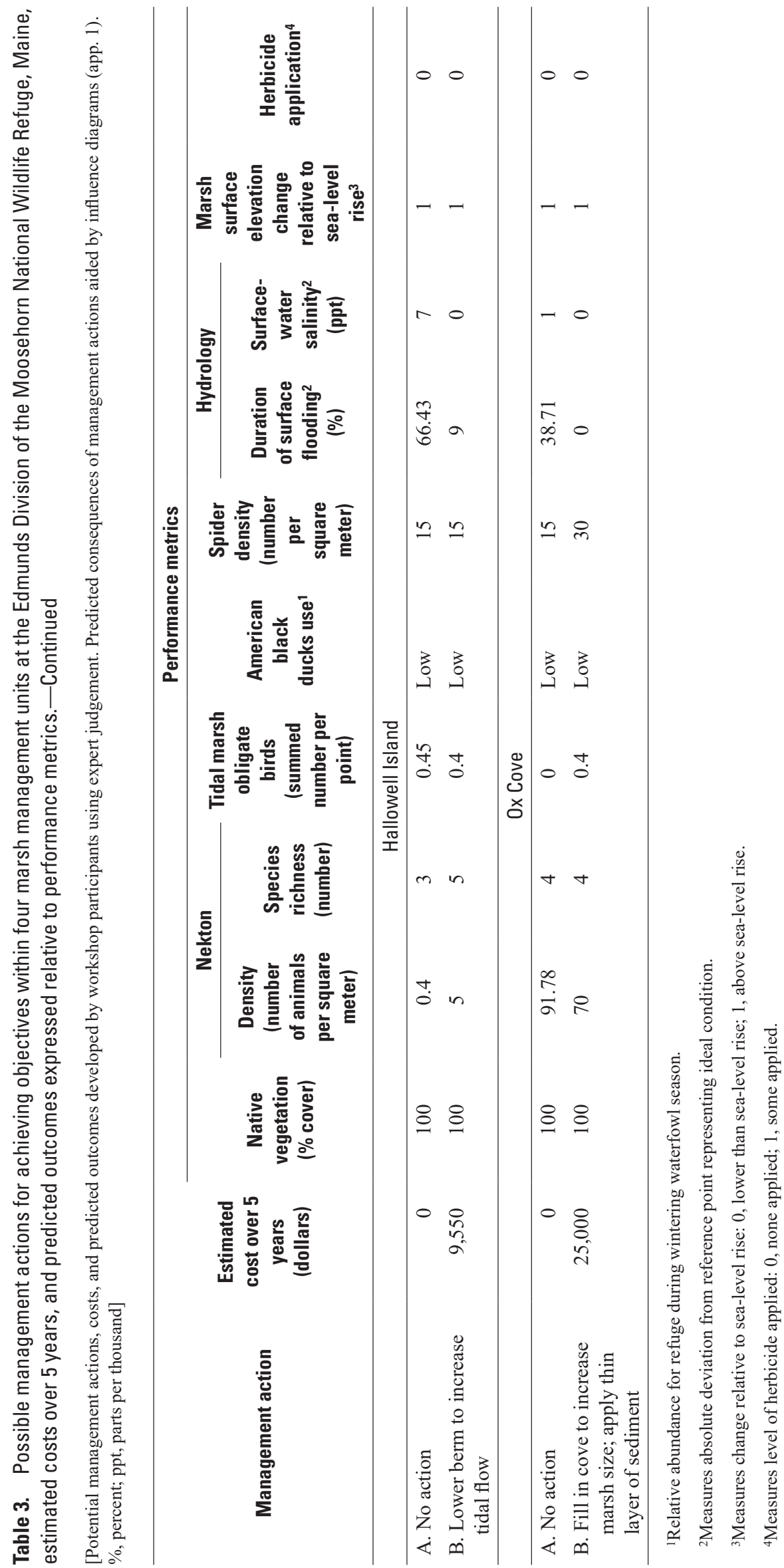




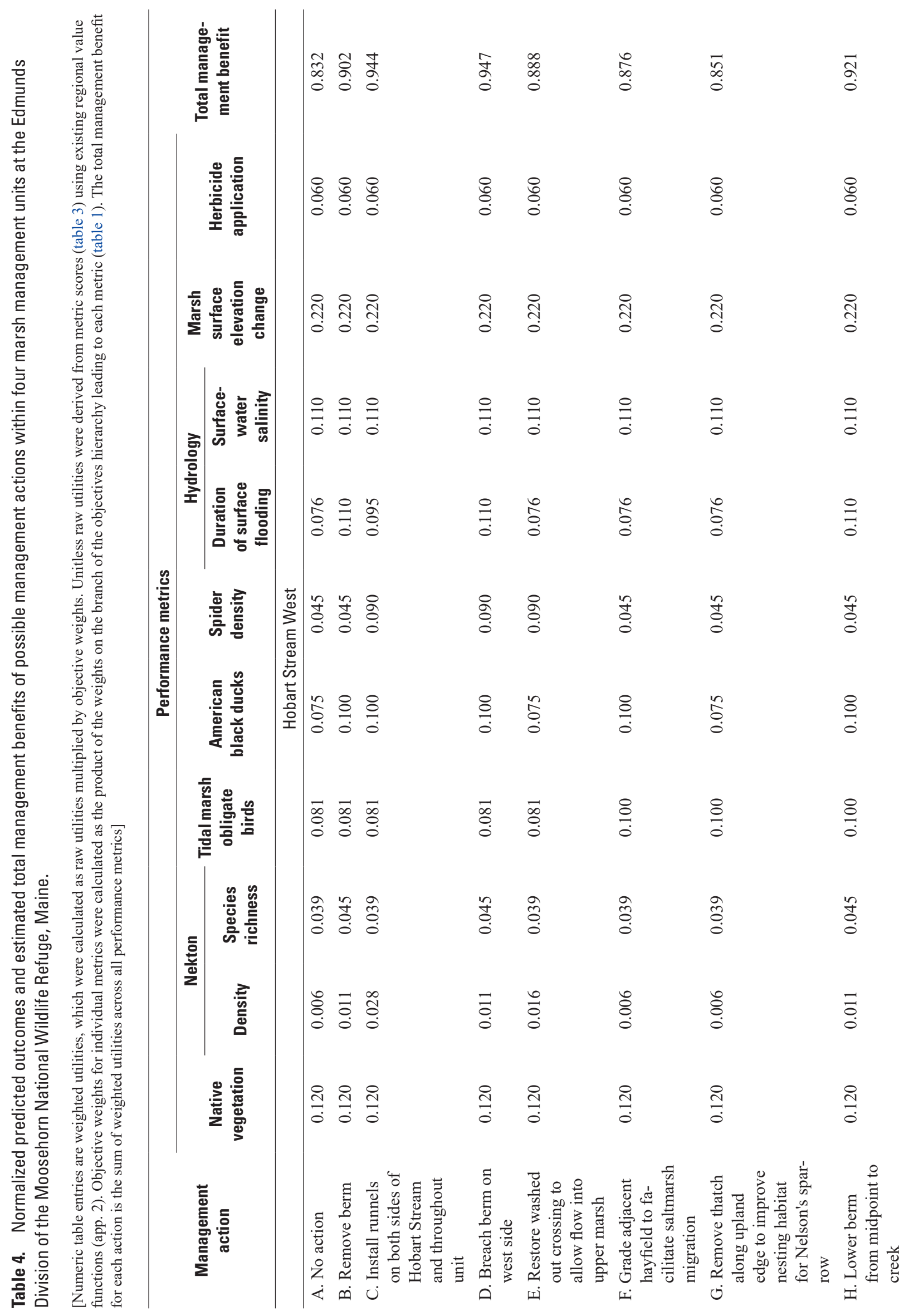




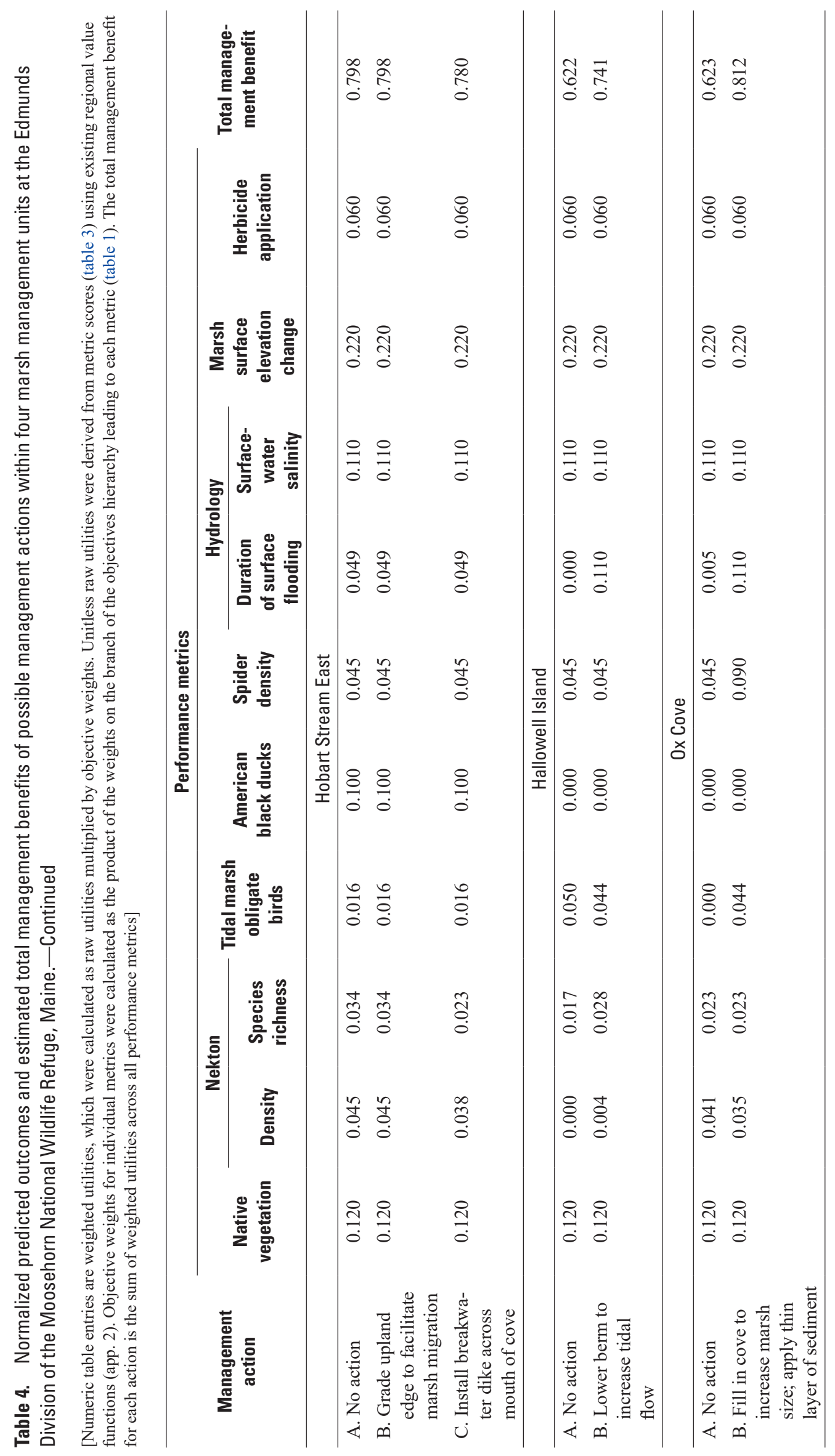


the decision-making framework to understand how a given portfolio could affect specific management objectives, the refuge-scale management benefits for individual performance metrics were compared between one optimal portfolio and those predicted with no management action taken.

\section{Results of Constrained Optimization}

Potential management actions identified to improve salt marsh integrity at the Moosehorn National Wildlife Refuge included breaching, lowering, or removing berms to restore natural hydrology; creating runnels to enhance drainage of water from the marsh surfaces; grading the upland edge of the marsh to facilitate marsh migration; and adding sediment to increase marsh size and elevation (table 3 ). For costs ranging from $\$ 0$ to $\$ 250,000$, the estimated management benefits for individual actions across all metrics, measured as weighted utilities, ranged from 0.622 (for implementing no action in the Hallowell Island marsh management unit) to 0.947 (for breaching the berm in the Hobart Stream West marsh management unit), out of a maximum possible total management benefit of 1.0 (table 3, table 4). Most commonly, the action with both the lowest management benefit and lowest cost was the "no action" alternative (management action A).

Constrained optimization was applied to identify the optimal management portfolios over 5 years for a range of total costs to the refuge. As total cost increased from $\$ 0$ (no action in either unit) to approximately $\$ 38,500$, the total management benefit at the refuge scale increased from 2.876 to 3.299 (a 14.7-percent increase; table 5) out of a possible maximum of 4.0 (the maximum possible management benefit of 1.0 for any management action, summed across the four marsh management units). Graphical analysis showed a fairly consistent increase in management benefit as costs increased to $\$ 1,000$ (fig. 3, portfolio 3). Portfolio 3 represented the turning point in the cost-benefit analysis; as expenditures increased beyond the cost of portfolio 3 , total management benefit continued to increase, but at a lower rate.

The two portfolios that yielded the greatest total management benefit per unit cost (table 5, portfolios 2 and 3) included management actions within Hobart Stream West only, the largest marsh management unit. The selected actions focused on improving nesting habitat for Nelson's sparrow and restoring hydrologic connections to the upper marsh. With a total cost up to $\$ 1,000$, these lowest-cost portfolios did not accommodate any actions for the other marsh management units, where the least costly individual action (grading the upland edge of Hobart Stream East) exceeded the portfolio cost constraints. Higher-cost portfolios (table 5, portfolios 5 through 8) included actions identified for Hallowell Island (lowering the berm to increase tidal flow) and Ox Cove (filling in the cove and applying a thin layer of sediment). However, the actions identified for Hobart Stream East did not yield an increase in total management benefit (table 4), and therefore were not included in any management portfolio (table 5).

Examination of the refuge-scale metric responses to actions included in portfolio 3, which is the turning point in the cost-benefit plot (fig. 3), revealed how implementation could affect specific management objectives. The actions included were predicted to achieve a small increase in the overall management benefits derived from density of nekton and a moderate increase in the benefit derived from density of spiders (as an indicator of trophic health; fig. 4). Ecologically, the combination of actions in portfolio 3 may result in an average 51-percent increase in nekton density (averaged across all marsh management units) and 25-percent increase in spider density (derived as the average difference between the predicted metric scores for the actions implemented in portfolio 3 and the "no-action" alternative; table 3). The management benefits predicted for portfolios 5 through 8 , at total costs up to $\$ 38,550$, were derived primarily from expected reductions in the duration of surface flooding (table 3, table 4). 
Table 5. Actions included in various management portfolios to maximize the total management benefits subject to increasing cost constraints at the Edmunds Division of the Moosehorn National Wildlife Refuge, Maine.

[Letter designations for actions refer to specific actions and are listed in table 3 and table 4. Portfolios represent the combination of potential actions, one per marsh management unit, that maximized the total management benefit across all units, subject to a refuge-wide cost constraint. The management actions constituting individual portfolios were selected using constrained optimization. The total cost represents the sum of costs estimated for each action included in the portfolio. The maximum possible total management benefit for the refuge is 4.0 , derived as the maximum possible total management benefit of 1.0 for any management action within one management unit, summed across four units]

\begin{tabular}{cccccccc}
\hline \multirow{2}{*}{ Portfolio } & \multicolumn{9}{c}{ Marsh management unit } & Total cost & \multicolumn{2}{c}{$\begin{array}{c}\text { Total management } \\
\text { benefit }\end{array}$} \\
\cline { 2 - 5 } (dollars) & $\begin{array}{c}\text { Hobart Stream } \\
\text { West }\end{array}$ & $\begin{array}{c}\text { Hobart Stream } \\
\text { East }\end{array}$ & Hallowell Island & 0x Cove & A & 0 & 2.876 \\
\hline 1 & A & A & A & A & A & 500 & 2.895 \\
2 & G & A & A & A & A & 1,000 & 2.932 \\
3 & E & A & A & A & 4,000 & 2.991 \\
4 & D & A & A & B & A & 9,550 & 2.995 \\
5 & A & D & A & B & A & 13,550 & 3.110 \\
6 & D & A & A & B & 29,000 & 3.180 \\
7 & D & A & B & B & 38,550 & 3.299 \\
\hline
\end{tabular}

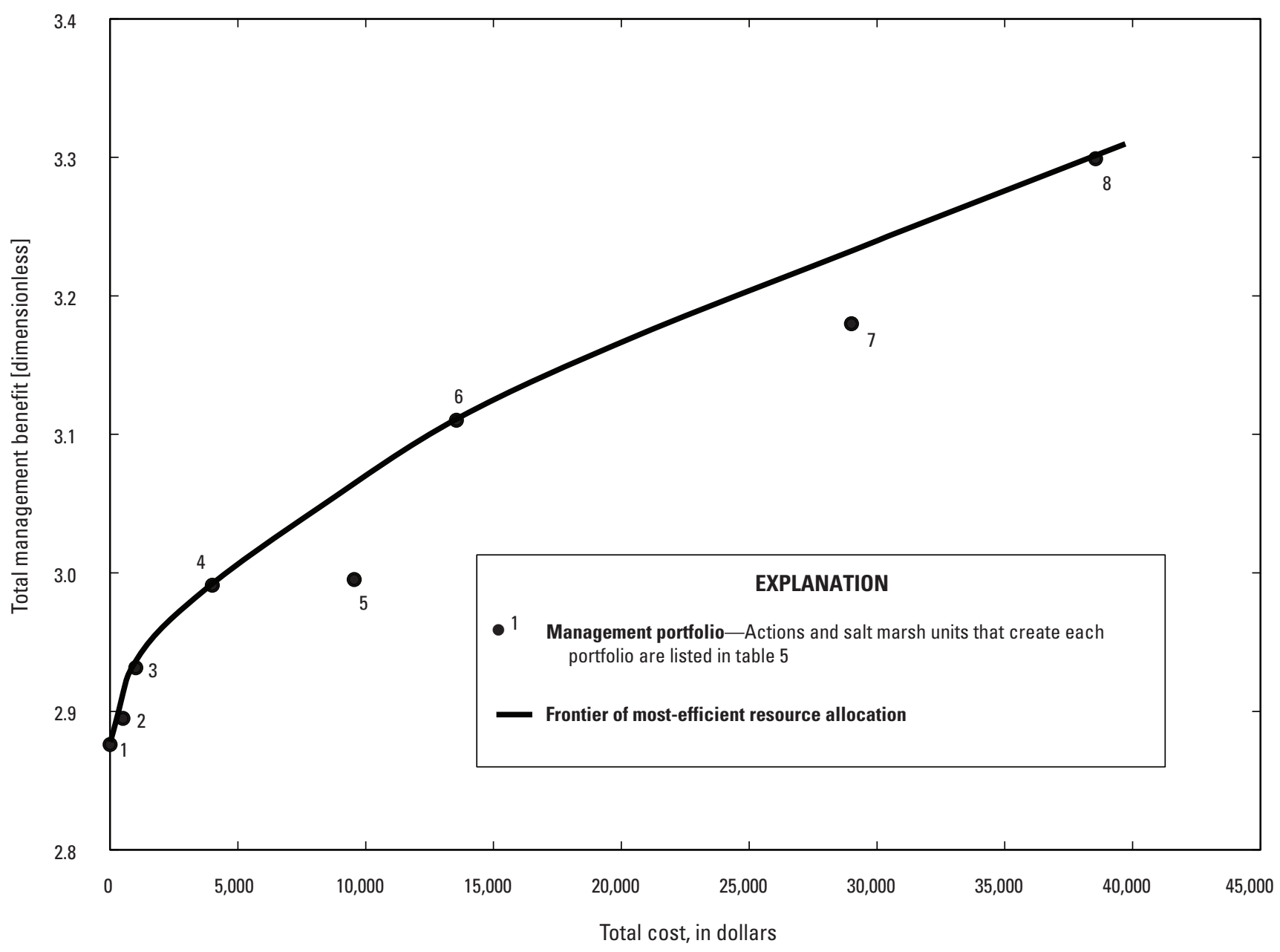

Figure 3. Graph showing predicted total management benefit of various portfolios, expressed as weighted utilities, relative to total cost at the Edmunds Division of the Moosehorn National Wildlife Refuge in Maine. Each portfolio (dot with number) represents a combination of four management actions, one per marsh management unit, as identified in table 5 . The line represents the efficient frontier for resource allocation. 


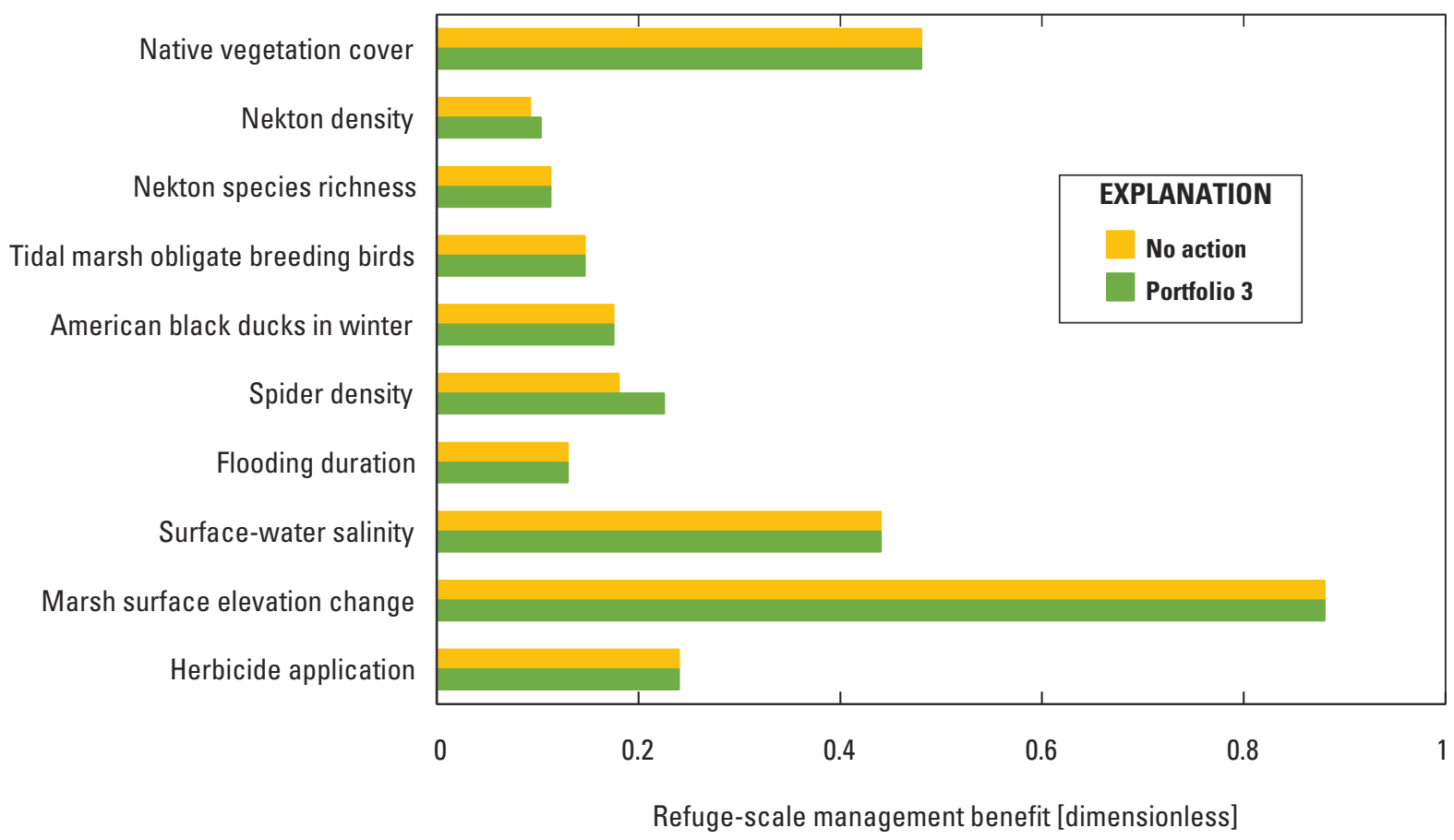

Figure 4. Bar chart showing predicted management benefit at the refuge scale for individual performance metrics, expressed as weighted utilities, resulting from implementation of the management actions included in portfolio 3 , in comparison to the management benefit from the baseline "no-action" portfolio, at the Edmunds Division of the Moosehorn National Wildlife Refuge in Maine. The actions included in each portfolio are listed in table 5 . 


\section{Considerations for Optimizing Salt Marsh Management}

A regional structured decision-making framework for salt marshes in NWRs in the northeastern United States was applied by the USGS, in cooperation with the FWS, to develop a tool for optimizing management decisions at the Moosehorn National Wildlife Refuge. Use of the existing regional framework and a rapid-prototyping approach permitted NWR biologists and managers, FWS regional authorities, and research scientists to construct a decision model for the refuge within the confines of a 1.5-day workshop. This preliminary prototype provides a local framework for decision making while revealing information needs for future iterations. Insights from this process may also be useful to inform future habitat management planning at the refuge.

The suite of potential management actions and predicted outcomes included in this prototype (table 3 ) were based on current understanding of the Moosehorn National Wildlife Refuge salt marshes and hypothesized process-response pathways (app. 1). Tidal flooding is the predominant physical control on the structure and function of salt marsh ecosystems (Pennings and Bertness, 2001), and there is widespread scientific effort to elucidate how salt marshes may respond to accelerating rates of sea-level rise and management strategies to enhance their sustainability (Kirwan and Megonigal, 2013; Roman, 2017). In particular, many salt marshes throughout the northeastern United States are degraded by roads, dikes, railroads, or other obstructions to tidal flow, and salt marsh restoration frequently focuses on reestablishing tidal flow (Konisky and others, 2006; Roman and Burdick, 2012). In this prototype, increasing tidal flow to upper marsh areas was predicted to improve overall management benefit for relatively low (Hobart Stream West marsh management unit, action E) or moderate (Hallowell Island marsh management unit, action B) cost (table 3, table 4). In addition, raising marsh elevation is frequently proposed to mitigate effects of increased inundation on coastal marsh soils (Wigand and others, 2017). In this prototype, the highest-cost portfolios (portfolios 7 and 8; table 5) included application of a thin layer of sediments to enhance elevation of the Ox Cove marsh management unit.

Multiple, interacting factors influence the long-term success of restoration actions in prolonging marsh integrity and improving marsh resilience (Roman, 2017). Future iterations of this decision model can incorporate improved understanding of both implementation costs and marsh responses to management actions. For example, removing the thatch and woody debris that accumulates along the upland edge of Hobart Stream West was suggested as a potential low-cost action to improve nesting habitat for Nelson's sparrow and other birds, such as Dolichonyx oryzivorus (bobolink), but the efficacy of this management technique is unknown. In addition, during construction of the regional decision model, lack of widely available data on rates of vertical marsh growth led to the adoption of a very coarse scale of measurement for change in marsh surface elevation relative to sea-level rise (table 1). Between October 2012 and August 2013, three surface elevation tables (Lynch and others, 2015) were installed in each marsh management unit to obtain high-resolution measurements of change in marsh surface elevation. Incorporating this information into subsequent iterations of this structured decision-making framework would likely improve predictions related to the potential for marsh surface elevation to keep pace with sea-level rise.

Results of constrained optimizations (table 5) based on the objectives, management actions, and predicted outcomes included in this prototype identified two particular areas in which to improve the utility of the prototype for refuge decision making. First, there were no potential actions for improving the integrity of Hobart Stream East included in an optimal portfolio. For both of the possible actions that were identified, the predicted total management benefit was equal to or lower than that predicted for implementing no action (table 4). This may lead managers to seek additional methods for improving the salt marsh integrity of Hobart Stream East. Second, the constrained optimizations analyzed in this report were based on approximations of management costs. As salt marsh management is undertaken around the region, a detailed list of actual expenses can be compiled, including staff time for project planning as well as materials, equipment, contracts, and staff time for implementation. This compilation of actual expenses will allow future iterations of the decision model to include more accurate cost estimates.

The prototype model for the Moosehorn National Wildlife Refuge provides a useful tool for decision making that can be updated in the future with new data and information. The spatial and temporal variability inherent in parameter estimates were not quantified during rapid prototyping. Previously, preliminary sensitivity analysis revealed little effect of incorporating ecological variation in abundance of marsh-obligate breeding birds on the optimal solutions for Prime Hook National Wildlife Refuge (Neckles and others, 2015). This lends confidence to use of this framework for decision making; however, including probability distributions for each performance metric in the decision model could be a high priority for future prototypes. Future monitoring of salt marsh integrity performance metrics will be useful to refine baseline parameter estimates and to determine the background rate of change in the absence of management actions; feedback from measured responses to management actions around the region will help reduce uncertainties surrounding management predictions. The structured decision-making framework applied here to the Moosehorn National Wildlife Refuge is based on a hierarchy of regional objectives and regional value functions relating performance metrics to perceived management benefits. It will be important to ensure that subsequent iterations reflect evolving management objectives and desired outcomes. Elements of the decision model could be further adapted, for example through differential weighting of objectives or altered value functions, to reflect specific, local management goals and mandates. Future optimization analyses that use this 
framework could also incorporate additional constraints on action selection, such as ensuring that particular actions within individual marsh management units are included in optimal management portfolios, to further tailor the model to refugespecific needs.

\section{References Cited}

Blomquist, S.M., Johnson, T.D., Smith, D.R., Call, G.P., Miller, B.N., Thurman, W.M., McFadden, J.E., Parkin, M.J., and Boomer, G.S., 2010, Structured decision-making and rapid prototyping to plan a management response to an invasive species: Journal of Fish and Wildlife Management, v. 1, no. 1, p. 19-32. [Also available at https://doi.org/ 10.3996/JFWM-025.]

Brooks, D.A., 2004, Modeling tidal circulation and exchange in Cobscook Bay, Maine: Northeastern Naturalist, v. 11, Special Issue no. 2 (Ecosystem modeling in Cobscook Bay, Maine-A boreal, macrotidal estuary), p. 23-50. [Also available at https://www.jstor.org/stable/60225647.]

Conroy, M.J., and Peterson, J.T., 2013, Decision making in natural resource management-A structured, adaptive approach: Chichester, United Kingdom, John Wiley and Sons, Ltd., 456 p. [Also available at https://doi.org/10.1002/ 9781118506196.]

Cowardin, L.M., Carter, V., Golet, F.C., and LaRoe, E.T., 1979, Classification of wetlands and deepwater habits of the United States: U.S. Fish and Wildlife Service FWS/ OBS-79/31, 131 p., accessed November 12, 2018, at https://www.fws.gov/wetlands/Documents/Classification-ofWetlands-and-Deepwater-Habitats-of-the-United-States.pdf.

Garrard, G.E., Rumpff, L., Runge, M.C., and Converse, S.J., 2017, Rapid prototyping for decision structuringAn efficient approach to conservation decision analysis, in Bunnefeld, N., Nicholson, E., and Milner-Gulland, E.J., eds., Decision-making in conservation and natural resource management: Cambridge, United Kingdom, Cambridge University Press, p. 46-64. [Also available at https://doi.org/10.1017/9781316135938.003.]

Gedan, K.B., Altieri, A.H., and Bertness, M.D., 2011, Uncertain future of New England salt marshes: Marine Ecology Progress Series, v. 434, p. 229-237. [Also available at https://doi.org/10.3354/meps09084.]

Gedan, K.B., Silliman, B.R., and Bertness, M.D., 2009, Centuries of human-driven change in salt marsh ecosystems: Annual Review of Marine Science, v. 1, no. 1, p. 117-141. [Also available at https://doi.org/10.1146/ annurev.marine.010908.163930.]
Gregory, R., Failing, L., Harstone, M., Long, G., McDaniels, T., and Ohlson, D., 2012, Structured decision making-A practical guide to environmental management choices: Chichester, United Kingdom, John Wiley and Sons, Ltd., 299 p. [Also available at https://doi.org/10.1002/ 9781444398557.]

Gregory, R.S., and Keeney, R.L., 2002, Making smarter environmental management decisions: Journal of the American Water Resources Association, v. 38, no. 6, p. 1601-1612. [Also available at https://doi.org/10.1111/ j.1752-1688.2002.tb04367.x.]

Hammond, J.S., Keeney, R.L., and Raiffa, H., 1999, Smart choices-A practical guide to making better life decisions: Boston, Harvard Business School Press, 242 p.

Jacobson, H.A., Jacobson, G.L., Jr., and Kelley, J.T., 1987, Distribution and abundance of tidal marshes along the coast of Maine: Estuaries, v. 10, no. 2, p. 126-131. [Also available at https://doi.org/10.2307/1352176.]

Keeney, R.L., and Raiffa, H., 1993, Decisions with multiple objectives-Preferences and value tradeoffs: Cambridge, United Kingdom, Cambridge University Press, 569 p. [Also available at https://doi.org/10.1017/CBO9781139174084.]

Kelley, J.T., Belknap, D.F., Jacobson, G.L., Jr., and Jacobson, H.A., 1988, The morphology and origin of salt marshes along the glaciated coastline of Maine, USA: Journal of Coastal Research, v. 4, no. 4, p. 649-666. [Also available at https://www.jstor.org/stable/4297467.]

Kirkwood, C.W., 1997, Strategic decision makingMultiobjective decision analysis with spreadsheets: Belmont, Calif., Duxbury Press, 345 p.

Kirwan, M.L., and Megonigal, J.P., 2013, Tidal wetland stability in the face of human impacts and sea-level rise: Nature, v. 504, no. 7478 , p. 53-60. [Also available at https://doi.org/ 10.1038/nature12856.]

Konisky, R.A., Burdick, D.M., Dionne, M., and Neckles, H.A., 2006, A regional assessment of salt marsh restoration and monitoring in the Gulf of Maine: Restoration Ecology, v. 14, no. 4, p. 516-525. [Also available at https://doi.org/ 10.1111/j.1526-100X.2006.00163.x.]

Lynch, J.C., Hensel, P., and Cahoon, D.R., 2015, The surface elevation table and marker horizon technique-A protocol for monitoring wetland elevation dynamics: National Park Service Natural Resource Report NPS/NCBN/NRR 2015/1078, [variously paged], accessed August 24, 2018, at https://irma.nps.gov/DataStore/DownloadFile/531681. 
Neckles, H.A., Guntenspergen, G.R., Shriver, W.G., Danz, N.P., Wiest, W.A., Nagel, J.L., and Olker, J.H., 2013, Identification of metrics to monitor salt marsh integrity on national wildlife refuges in relation to conservation and management objectives: U.S. Fish and Wildlife Service, prepared by U.S. Geological Survey, 226 p., accessed May 1, 2018, at https://ecos.fws.gov/ServCat/Reference/ Profile/37795.

Neckles, H.A., Lyons, J.E., Guntenspergen, G.R., Shriver, W.G., and Adamowicz, S.C., 2015, Use of structured decision making to identify monitoring variables and management priorities for salt marsh ecosystems: Estuaries and Coasts, v. 38, no. 4, p. 1215-1232. [Also available at https://doi.org/10.1007/s12237-014-9822-5.]

Pennings, S.C., and Bertness, M.D., 2001, Salt marsh communities, in Bertness, M.D., Gaines, S.D., and Hay, M.E., eds., Marine community ecology: Sunderland, Mass., Sinauer Associates, p. 289-316.

Roman, C.T., 2017, Salt marsh sustainability-Challenges during an uncertain future: Estuaries and Coasts, v. 40, no. 3, p. 711-716. [Also available at https://doi.org/10.1007/ s12237-016-0149-2.]
Roman, C.T., and Burdick, D.M., eds., 2012, Tidal marsh restoration-A synthesis of science and practice: Washington, D.C., Island Press, 406 p. [Also available at https://link.springer.com/content/pdf/10.5822\%2F978-161091-229-7.pdf.]

Steinkamp, M., 2008. New England/mid-Atlantic coast bird conservation (BCR 30) implementation plan: Laurel, Md., Atlantic Coast Joint Venture, 251 p., accessed August 15, 2018, at https://www.acjv.org/BCR_30/BCR30_June_23_ 2008_final.pdf.

U.S. Fish and Wildlife Service [FWS], 2016, Salt marsh integrity and Hurricane Sandy vegetation, bird and nekton data: U.S. Fish and Wildlife Service database, https://ecos.fws.gov/ServCat/Reference/Profile/121918.

U.S. North American Bird Conservation Initiative, 2020, Bird conservation regions: U.S. North American Bird Conservation Initiative web page, accessed July 6, 2020, at https://nabci-us.org/resources/bird-conservation-regions/.

Wigand, C., Ardito, T., Chaffee, C., Ferguson, W., Paton, S., Raposa, K., Vandemoer, C., and Watson, E., 2017, A climate change adaptation strategy for management of coastal marsh systems: Estuaries and Coasts, v. 40, no. 3, p. 682-693. [Also available at https://doi.org/10.1007/s12237015-0003-y. 


\section{Appendix 1. Regional Influence Diagrams}

The influence diagrams (following the style of prototype diagrams in Neckles and others, 2015) in this appendix (figs. 1.1-1.8) relate possible management strategies to performance metrics. Shapes represent elements of decisions, as follows: rectangles for actions, rectangles with rounded corners for deterministic factors, ovals for stochastic events, and hexagons for consequences expressed as a performance metric.

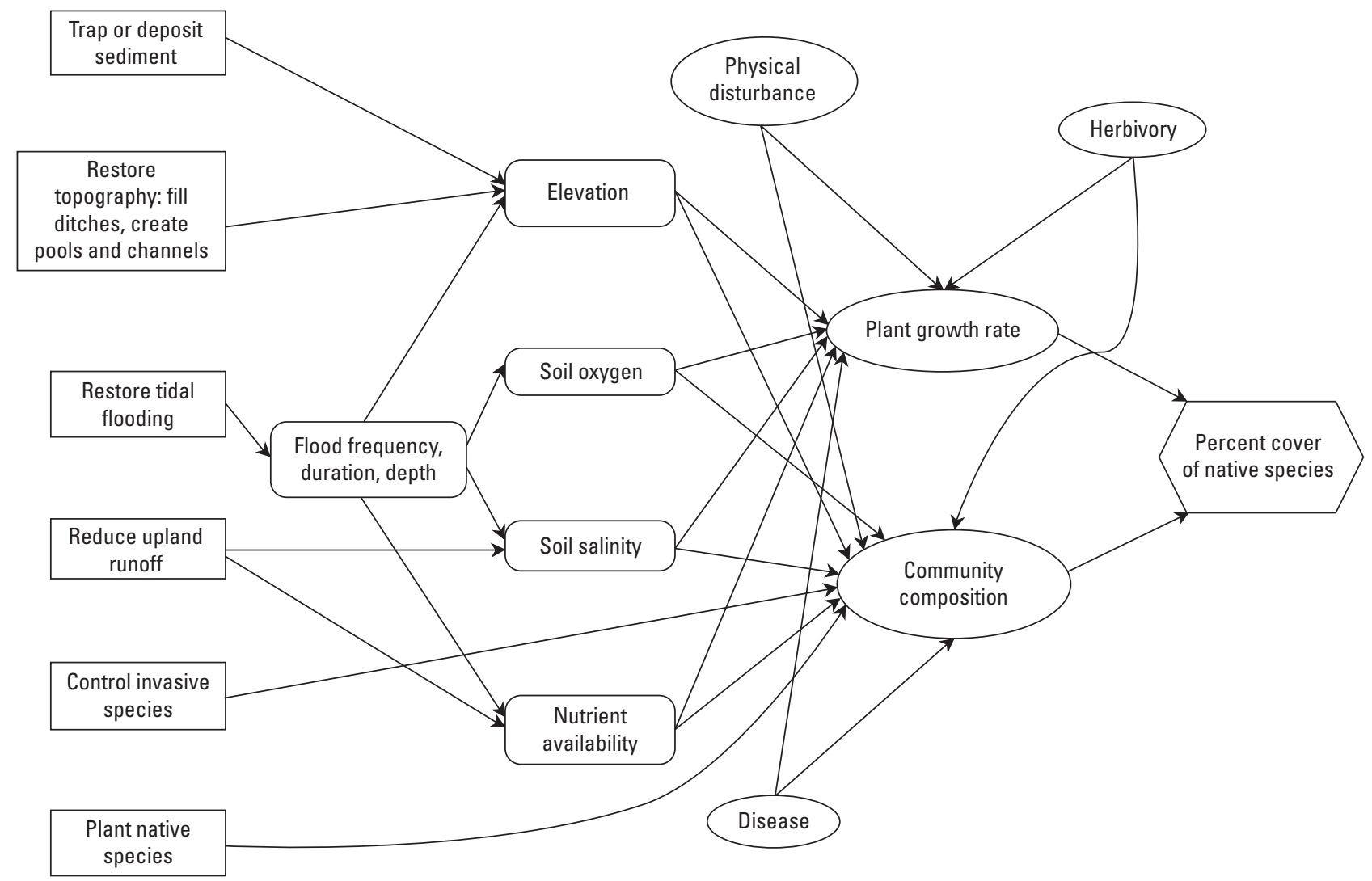

Figure 1.1. Influence diagram used to estimate percent cover of native vegetation in response to implementing certain management actions. 


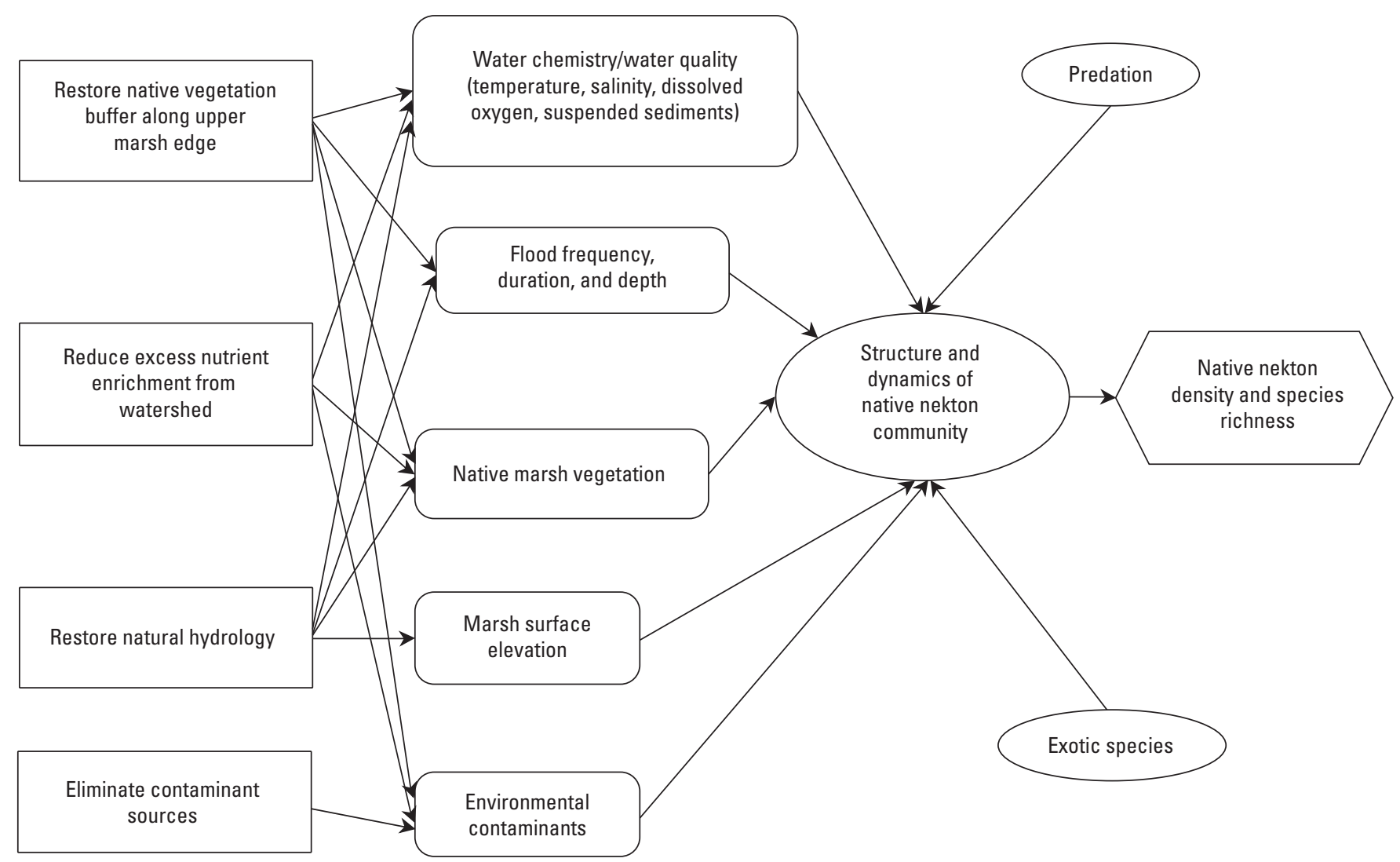

Figure 1.2. Influence diagram used to estimate nekton density and species richness in response to implementing certain management actions. 


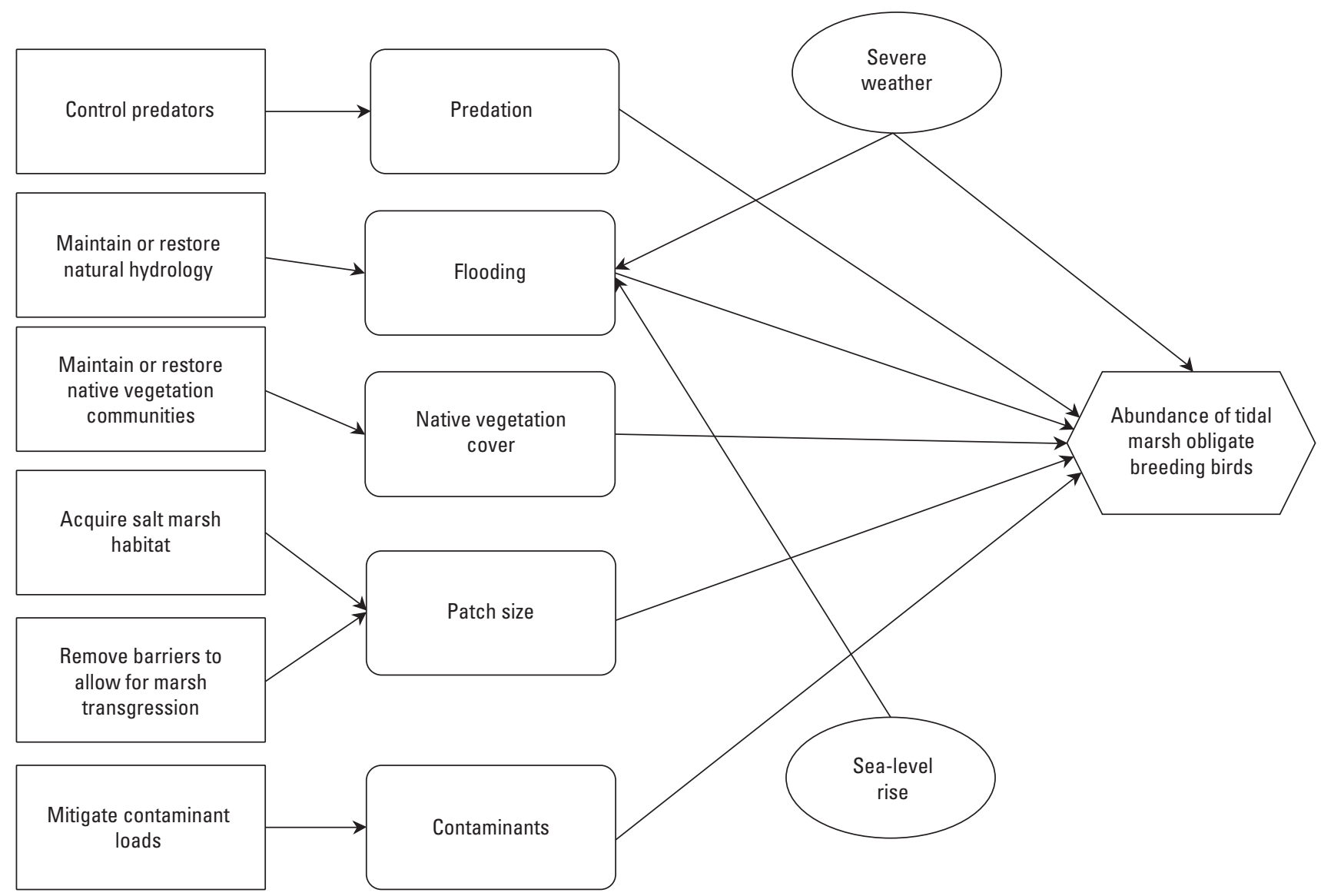

Figure 1.3. Influence diagram used to estimate abundance of tidal marsh obligate breeding birds in response to implementing certain management actions. 


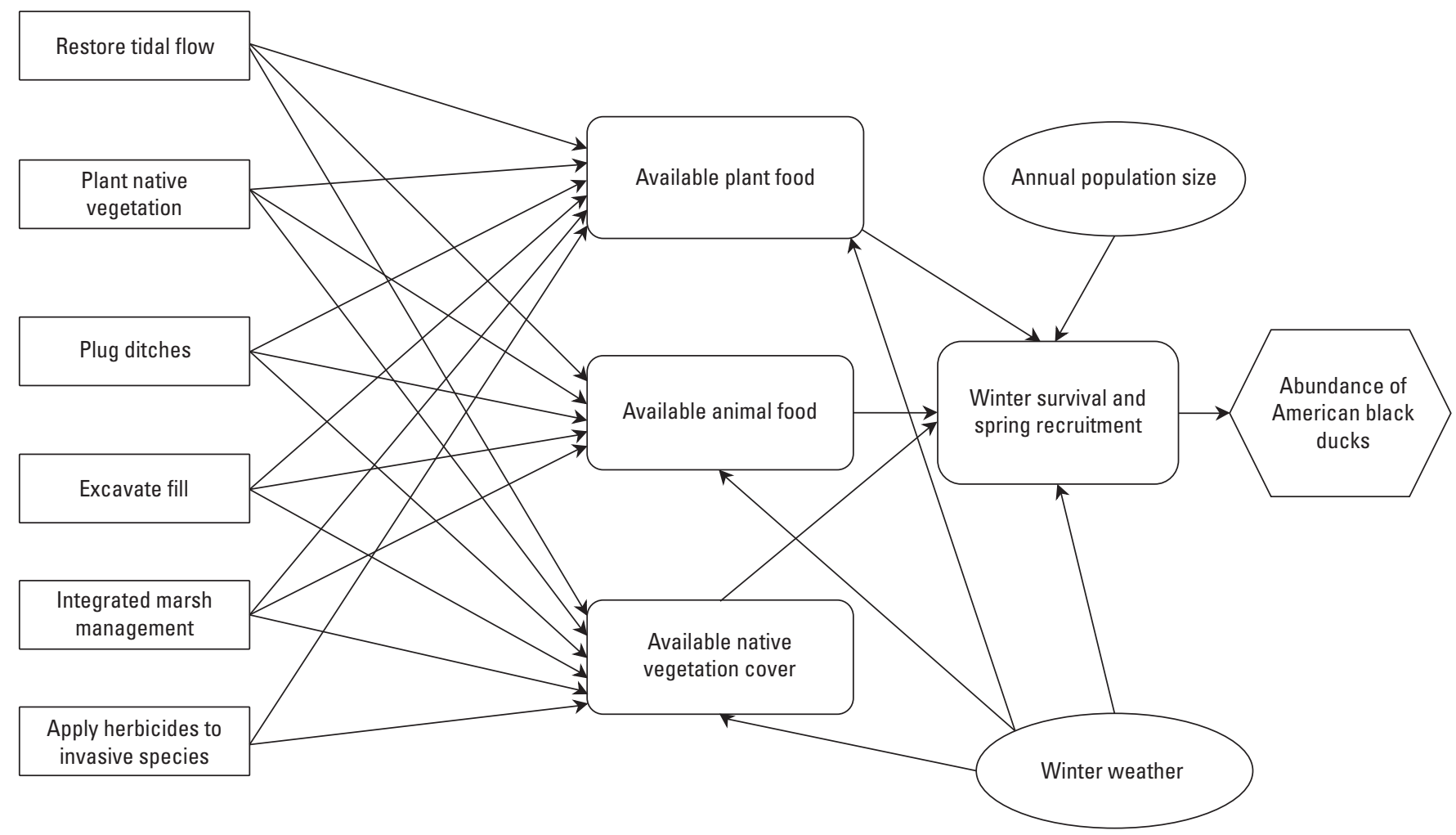

Figure 1.4. Influence diagram used to estimate abundance of American black ducks in winter, as indicator species for nonbreeding wetland birds, in response to implementing certain management actions. 


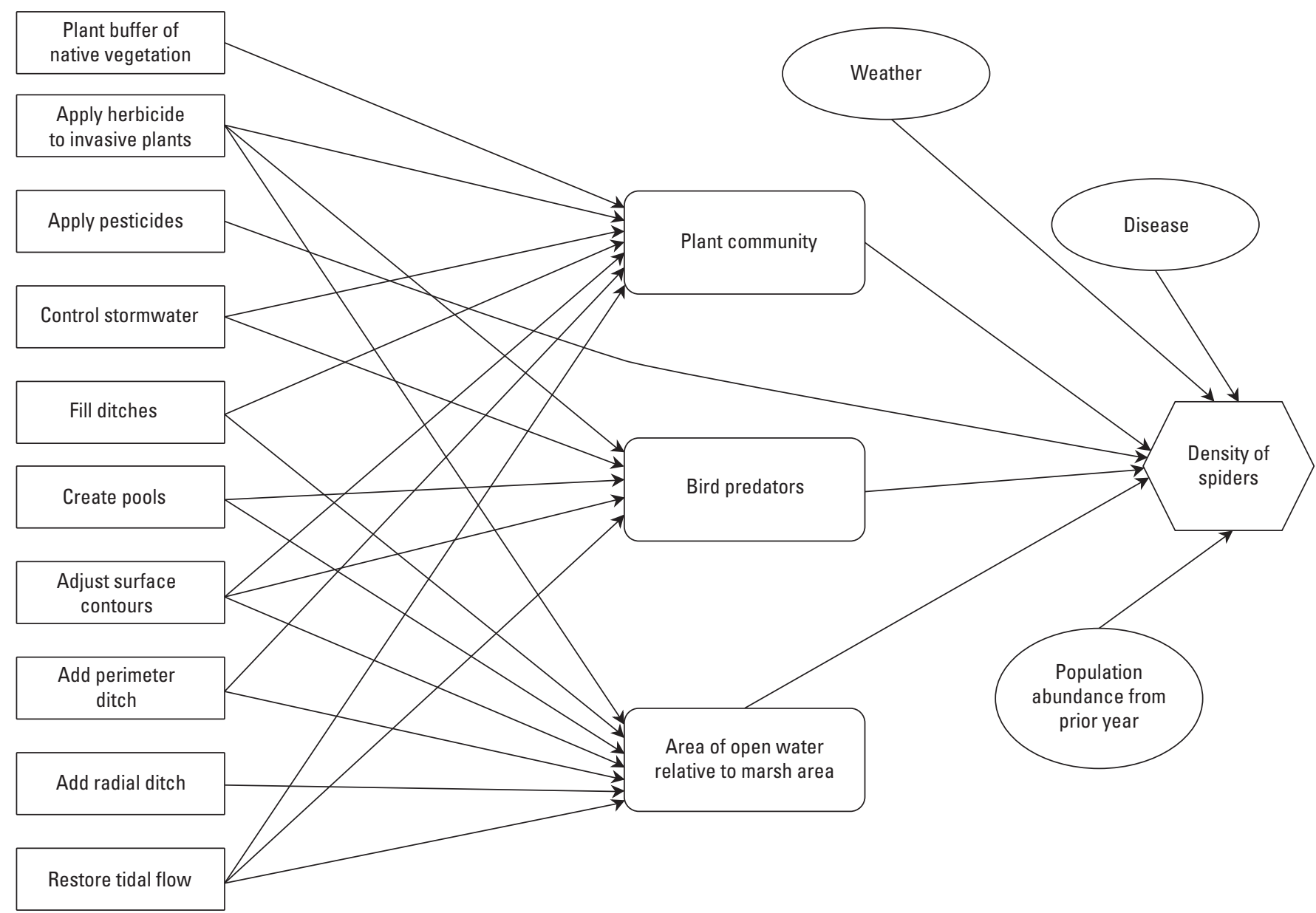

Figure 1.5. Influence diagram used to estimate density of spiders, as indicator of trophic health, in response to implementing certain management actions. 


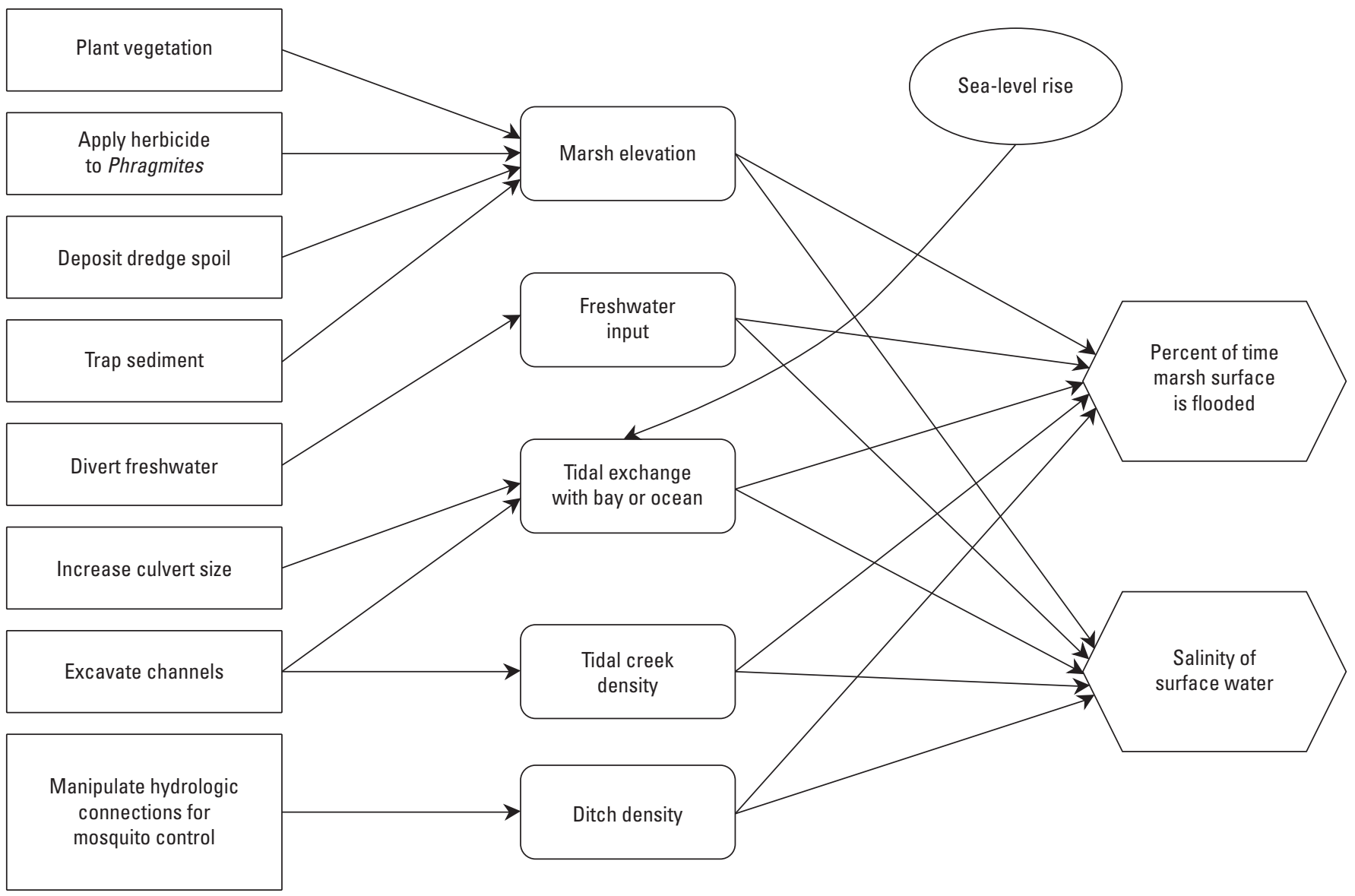

Figure 1.6. Influence diagram used to estimate percent of time marsh surface is flooded and salinity of marsh surface water in response to implementing certain management actions. 


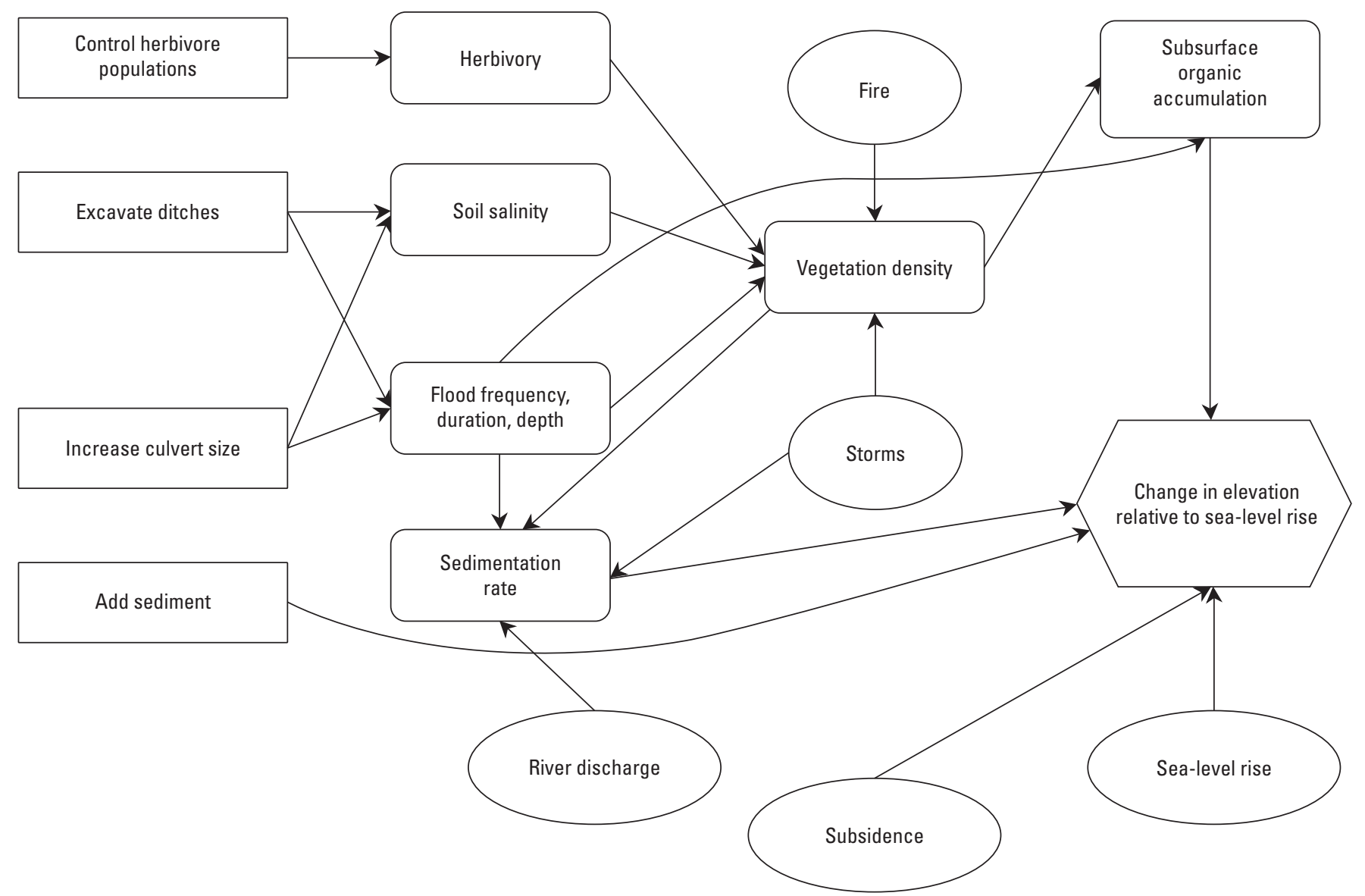

Figure 1.7. Influence diagram used to estimate change in elevation of the marsh surface relative to sea-level rise in response to implementing certain management actions.

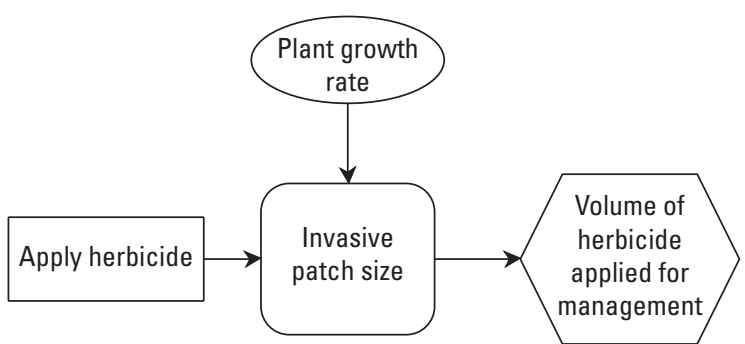

Figure 1.8. Influence diagram used to estimate volume of herbicide that could be applied if a decision was made to use chemical control for removing unwanted vegetation.

\section{Reference Cited}

Neckles, H.A., Lyons, J.E., Guntenspergen, G.R., Shriver, W.G., and Adamowicz, S.C., 2015, Use of structured decision making to identify monitoring variables and management priorities for salt marsh ecosystems: Estuaries and Coasts, v. 38, no. 4, p. 1215-1232. [Also available at https://doi.org/10.1007/s12237-014-9822-5.] 


\section{Appendix 2. Utility Functions for the Moosehorn National Wildlife Refuge}

Utilities $[u(x)]$ are derived as monotonically increasing, monotonically decreasing, or step functions over the range of performance metric $x$. In the functions in figures $2.1-2.10, x$, Low, High, and $\rho$ are expressed in performance metric units; Low and High represent the endpoints of the given metric range for the Moosehorn National Wildlife Refuge; and $\rho$ represents a shape parameter derived by stakeholder elicitation (Neckles and others, 2015). Break points in step functions were also derived by stakeholder elicitation.

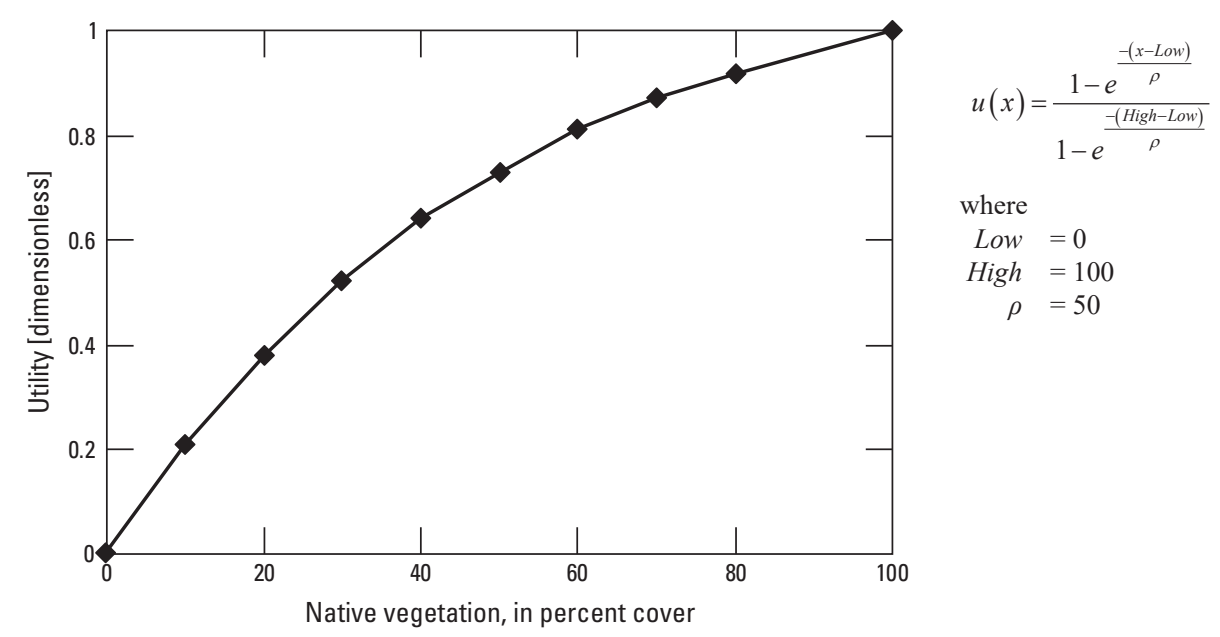

Figure 2.1. Native vegetation at the Edmunds Division of the Moosehorn National Wildlife Refuge, Maine.

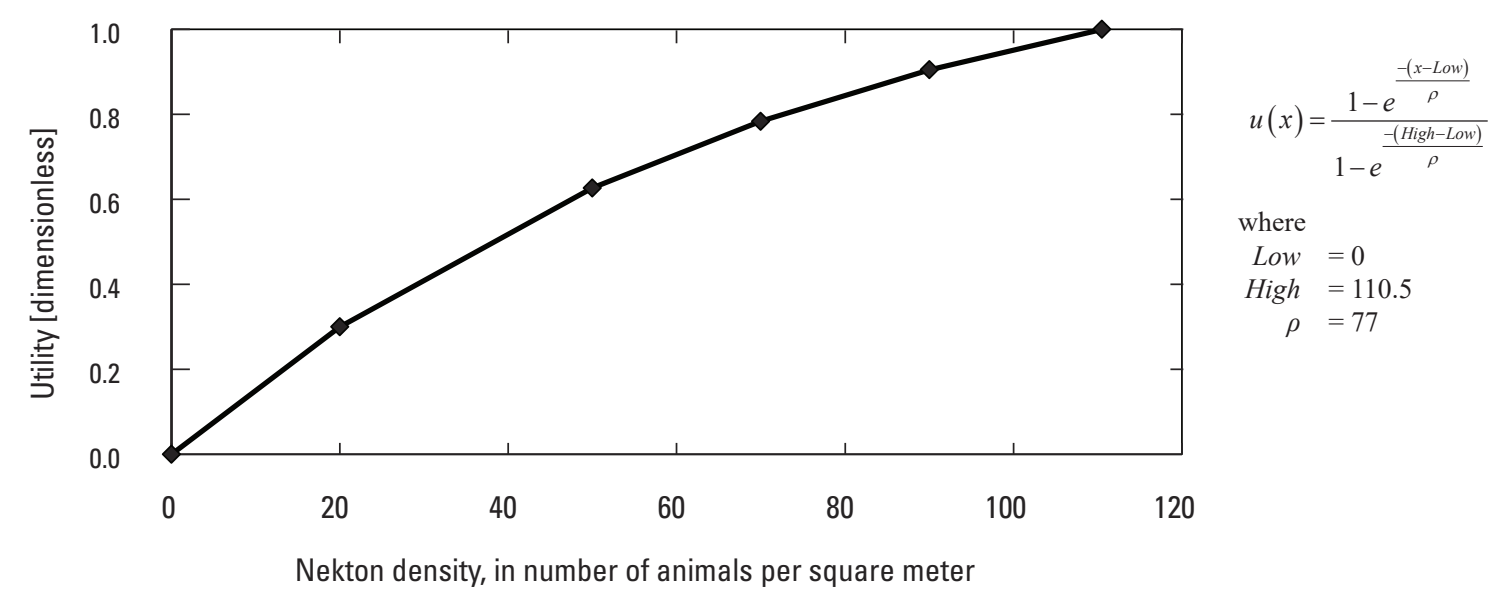

Figure 2.2. Native nekton density at the Edmunds Division of the Moosehorn National Wildlife Refuge, Maine. 


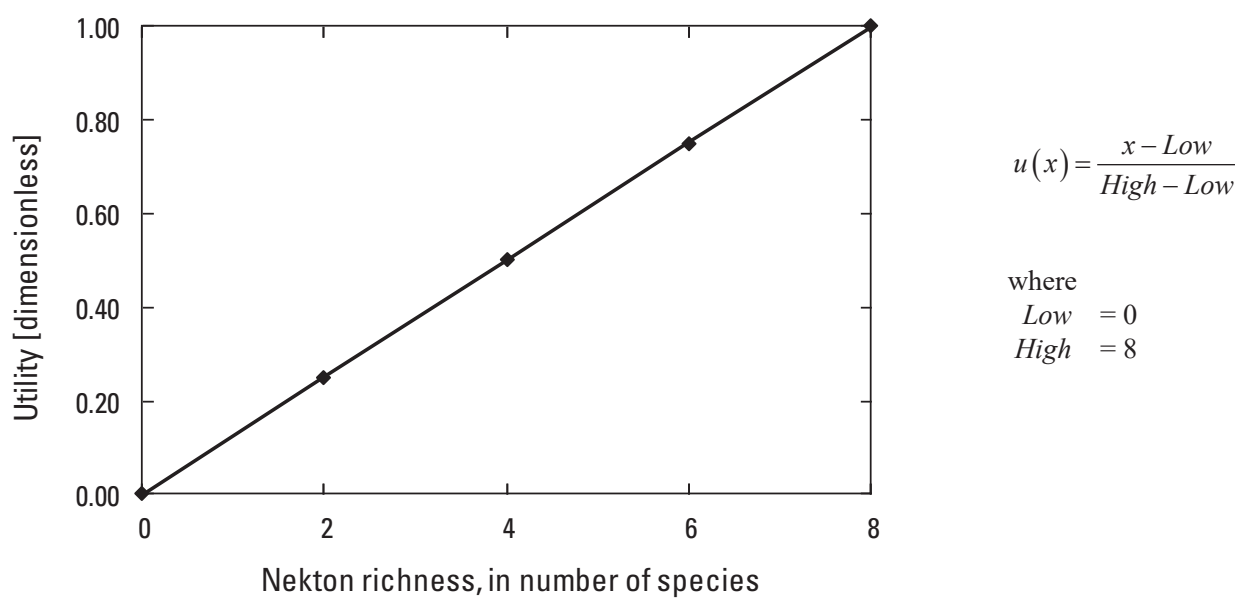

Figure 2.3. Native nekton species richness at the Edmunds Division of the Moosehorn National Wildlife Refuge, Maine.

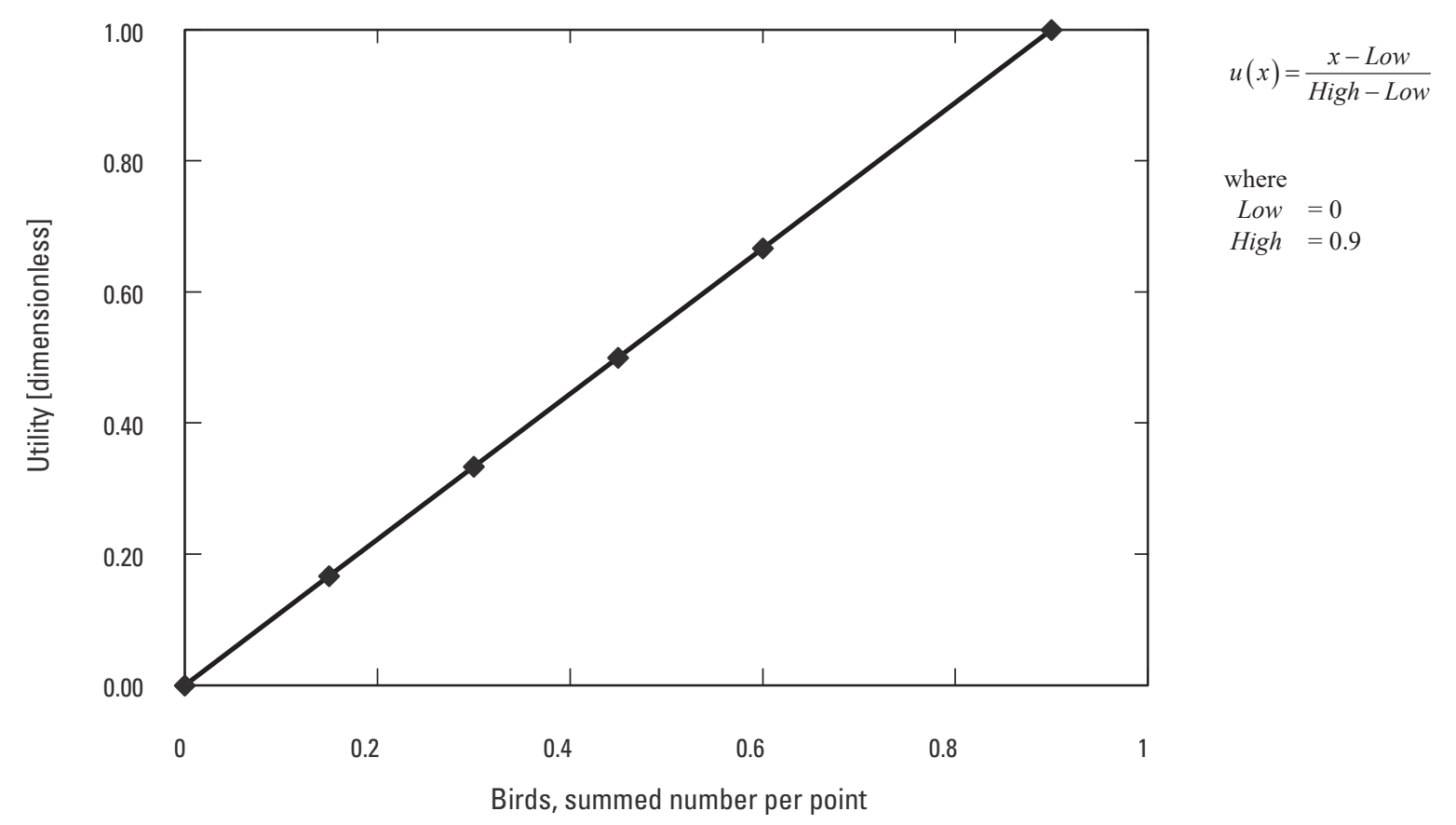

Figure 2.4. Tidal marsh obligate birds at the Edmunds Division of the Moosehorn National Wildlife Refuge, Maine. 


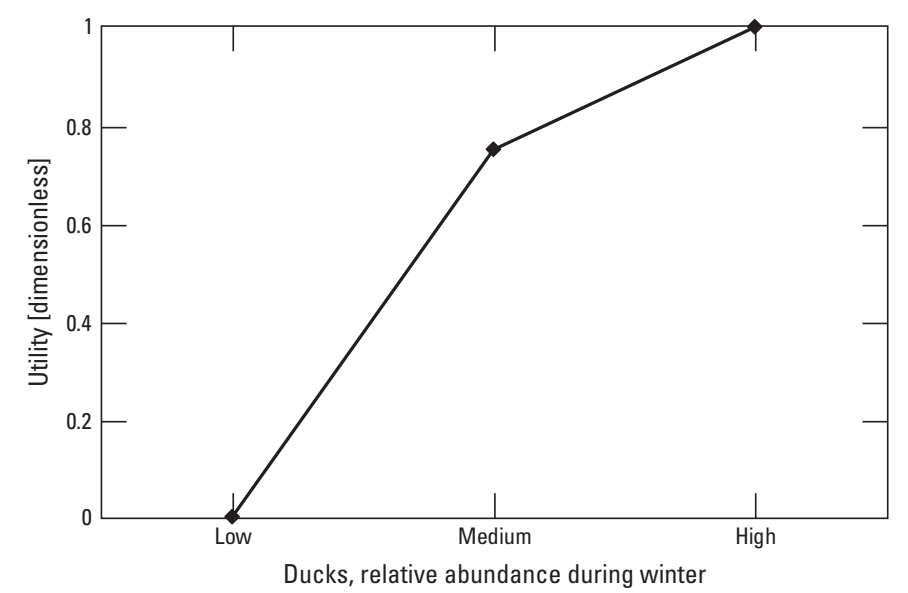

If $x=$ Low, then $u(x)=0$

If $x=$ Medium, then $u(x)=0.75$

If $x=H i g h$, then $u(x)=1$

Figure 2.5. American black ducks at the Edmunds Division of the Moosehorn National Wildlife Refuge, Maine.

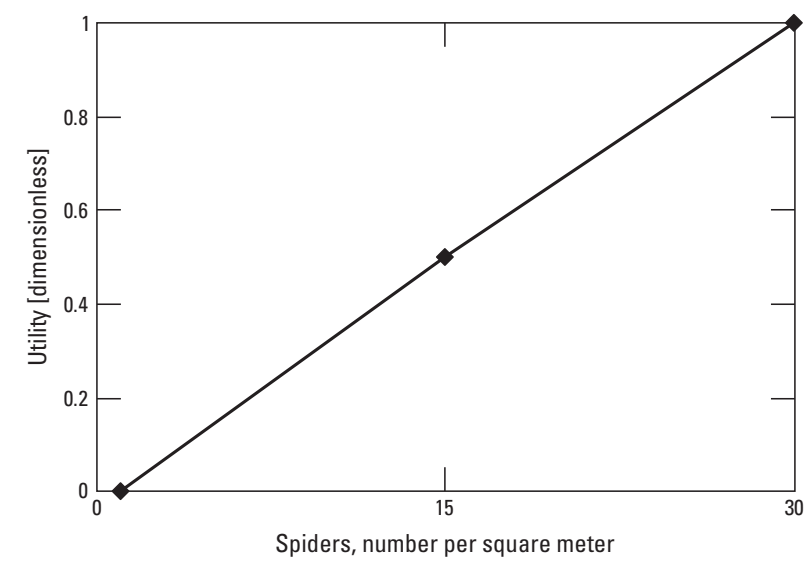

$$
\begin{aligned}
& \text { If } x \leq 15 \text {, then } u(x)=0.5 \times \frac{x-1}{14} \\
& \text { If } x>15 \text {, then } u(x)=0.5+\left(0.5 \times \frac{x-15}{15}\right)
\end{aligned}
$$

Figure 2.6. Marsh spiders at the Edmunds Division of the Moosehorn National Wildlife Refuge, Maine.

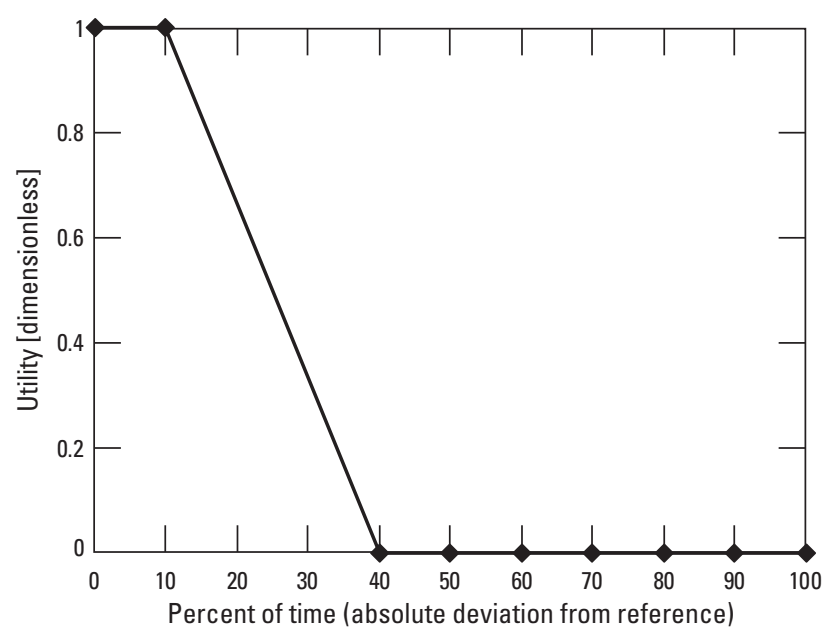

If $x \leq 10$, then $u(x)=1$

If $x \geq 40$, then $u(x)=0$
If $10<x<40$, then $u(x)=1-\frac{x-10}{30}$

Figure 2.7. Duration of surface flooding at the Edmunds Division of the Moosehorn National Wildlife Refuge, Maine. 


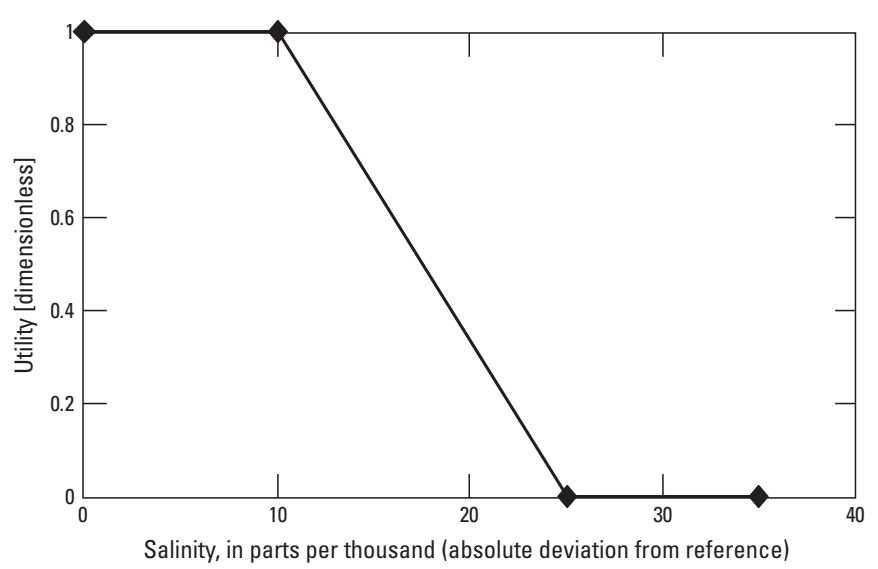

If $x \leq 10$, then $u(x)=1$
If $x \geq 25$, then $u(x)=0$
If $10<x<25$, then $u(x)=1-\frac{x-10}{15}$

Figure 2.8. Salinity of surface water at the Edmunds Division of the Moosehorn National Wildlife Refuge, Maine.

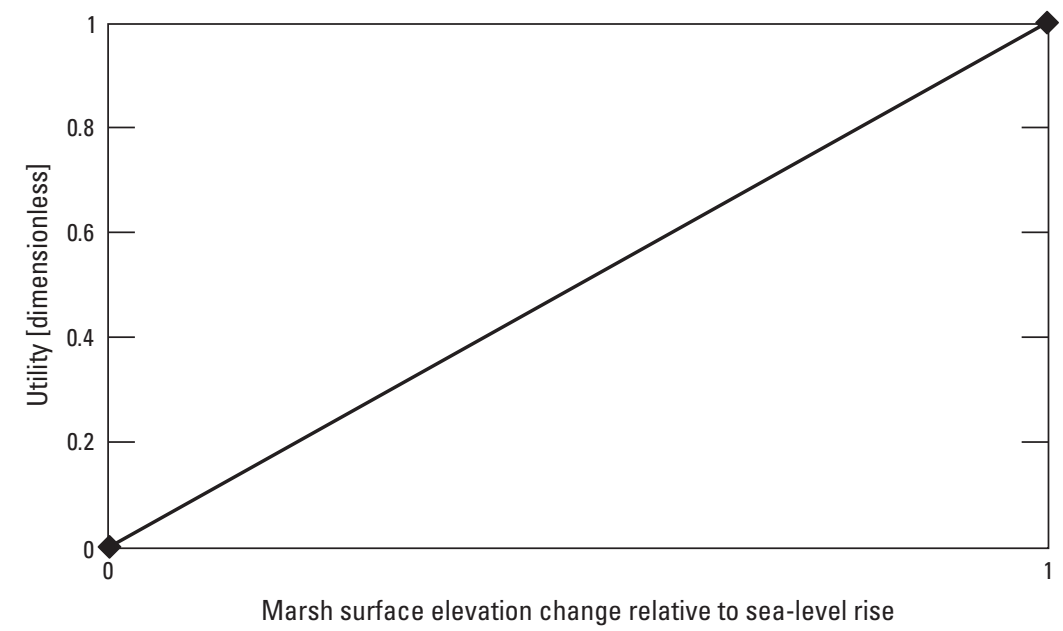

$$
\begin{aligned}
& u(x)=\frac{x-\text { Low }}{\text { High }- \text { Low }} \\
& \text { where } \\
& \qquad \begin{array}{l}
\text { Low } \quad=0, \text { lower than sea-level rise } \\
\text { High } \quad=1 \text {, above sea-level rise }
\end{array}
\end{aligned}
$$

Figure 2.9. Change in marsh surface elevation relative to sea-level rise at the Edmunds Division of the Moosehorn National Wildlife Refuge, Maine.

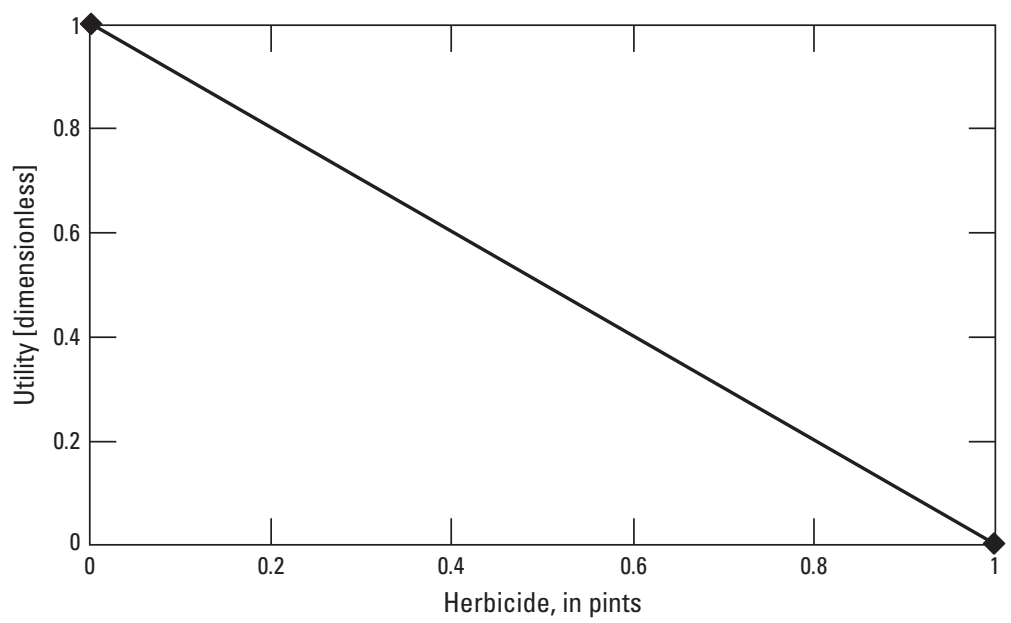

$$
\begin{aligned}
& u(x)=\frac{\text { High }-x}{\text { High }- \text { Low }} \\
& \text { where } \\
& \begin{aligned}
\text { Low } & =0 \\
\text { High } & =1
\end{aligned}
\end{aligned}
$$

Figure 2.10. Application of herbicides at the Edmunds Division of the Moosehorn National Wildlife Refuge, Maine. 


\section{Reference Cited}

Neckles, H.A., Lyons, J.E., Guntenspergen, G.R., Shriver, W.G., and Adamowicz, S.C., 2015, Use of structured decision making to identify monitoring variables and management priorities for salt marsh ecosystems: Estuaries and Coasts, v. 38, no. 4, p. 1215-1232. [Also available at https://doi.org/10.1007/s12237-014-9822-5.] 
For more information, contact:

Director, Eastern Ecological Science Center

U.S. Geological Survey

11649 Leetown Road

Kearneysville, WV 25430

or visit our website at

https://www.usgs.gov/centers/eesc

Publishing support provided by the

Pembroke Publishing Service Center 


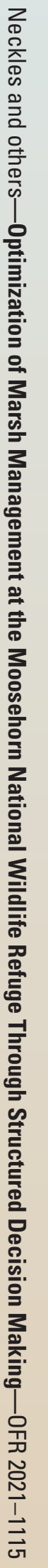

